\title{
تطوير الموارد البشرية في جامعة صحار في ضوي معايير الهيئة العمانية للاعتماد الأكاديمي
}

عبر الرحمن بن سالم بن حمدان القاسمي

التميز و الجودة النوعيــة فـــي الأداء كاتجـــاه تطوير مي معاصر .

وتسعى سلطنة عمسـان مـن خــلال

الاستر اتيجية المعتمدة لتتمية المو ارد البـشرية وهي إحدى الاستر اتيجيات الرئيسية المعتمــدة لتحقيق الرؤية المسنقبلية للاقتهـصاد العدــاني

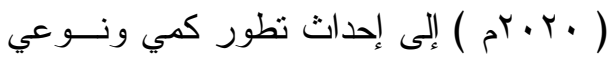
في كافة مجالات التعليم العام و التعليم الفنـي لــي و التدريب المهني و التعليم العالي و الخــدمات الصحية. وذلك من خلال تحقيــق التــــازن الاقتصادي و النمو المتو اصل، وتتويع مصادر ملهر الاخل، وتتمية القطاع الخاص فكل ذللك لــن يتأتى دون وضع استر اتيجية و اقعية و ومرنــة

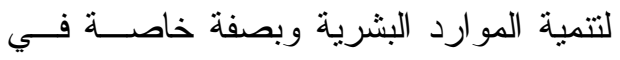

$$
\text { التعليم العالي. }
$$

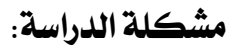

خطا التعليم العالي في سلطنة عمــان

خطو ات سريعة وثابتة؛ حيث شجعت السلطنة التعليم بكل إمكاناتها، ورصدت وندابهـ ما يحتاج إليه من إمكانات مادية وبشرية، وذللك لأهميته في لي

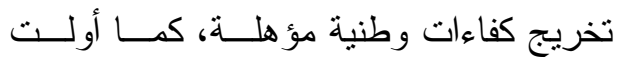

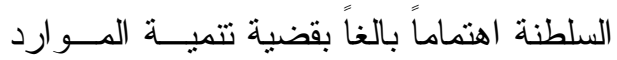

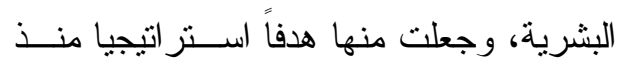

أصبحت جودة أداء التعلــيم العــالي موضع اهتمام كبير على الصعيدين العربي

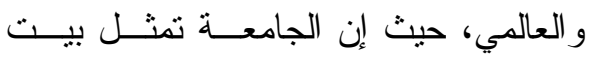

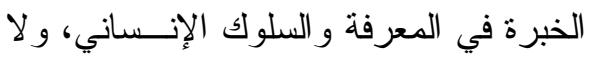
يقتصر دور ها على تزويد الطلبة بالمعارف

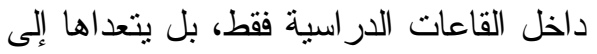
النهوض بالمجتمع، وقيادة عمليات التغييــر و التطوير لتحقيق أهداف التنمية الثاملة في

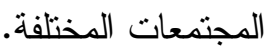
لذا اتجهت كثير مـن الــدول إلـى

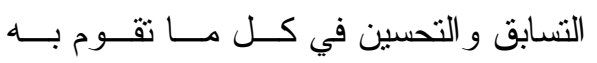
جامعاتها من أنشطة، وما تطبقه من أساليب

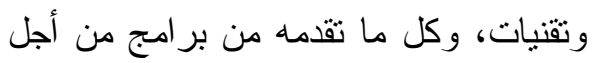

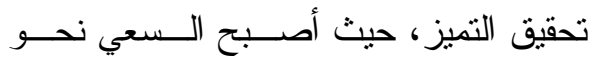

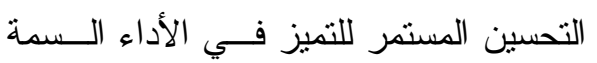
الأساسية للعمل الإداري في العصر الر اهن

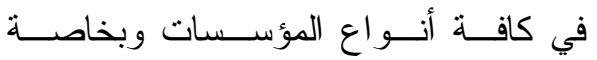
المؤسسات التعليمية من أجل إحــــاث نقلـــة

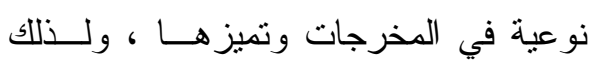

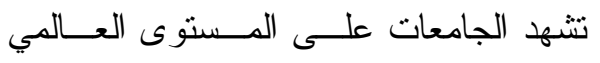
محاو لات جادة لنطوير ها وتحديثها، وتقيــيم الأداء وتحسينه من خلال التأكيد علي مفاهيم 
مطلع النهضة في السبعينات ، وفي الوقـت الأكاديمي. مما يجعلها أمر جدير بالدراســة

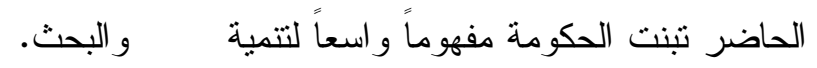

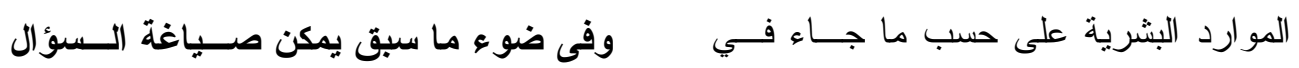

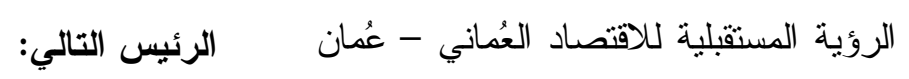

كيف يمكن تطوير المــوارد البــشرية

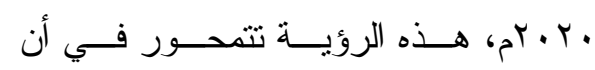
بجامعة صحار في ضـــوء معسايير الهيئــة الانسان غاية للتتمية وليس وسيلة لتحقيقهـ

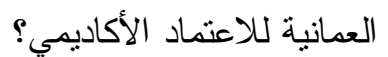

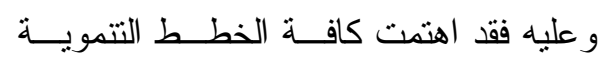
المتعاقبة على تتمية الموارد البشرية وفــق لهن ويتقرع من هذا التساؤل الرئيس عدة تساؤلات فر عية تتمنل في الآتي: ا ـ ما الإطار الفكري لمعايير الهيئة العامة

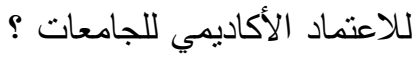

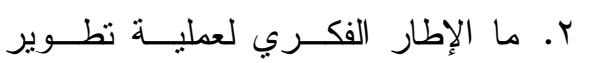

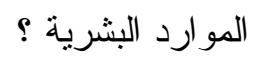

r. ما واقع تطوير الموارد البشرية بجامعة لبنة صحار في ضوء تطبيق معايير العيئة العمانية للاعتماد الأكاديمي؟ ـ. هل يختلف و اقــع تطــوير المــوارد البشرية في ضوء معايير الهيئة العامة

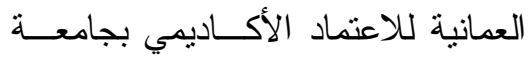
صحار باختلاف متغير ات الدر اسة؟ ه. ما التصور المقترح لتطوير المــوارد

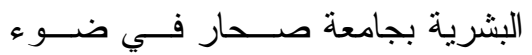
معسيير الهيئــة العمانيـــة للاعتمـــاد الأكاديمي في سلطنة عمان ؟

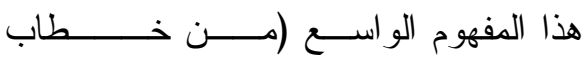

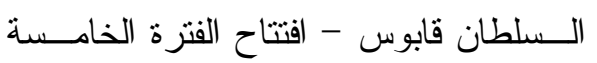
لمجلس عمان لعام (1) • بم). لذا جاءت هذه الدر اسة للكثف عـن و اقع تطوير الموارد البشرية بجامعة صحار في ضوء معايير الهيئة العمانيــة للاعتمـــاد الاكاديمي، على الرغم مــن وجـــود جهــة مرجعية للمتابعة و التنقيق على الجامعسـات الخاصة بسلطنة عمان وهي الهيئة العمانيـــة للاعتماد الأكاديمي الني حـددت معسايير ا

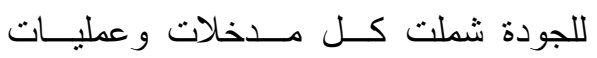
مؤسسات التعليم العالي بسلطنة عمان بمــا

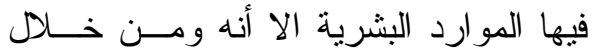
استطلاع أولي أجري مع عدد من العاملين

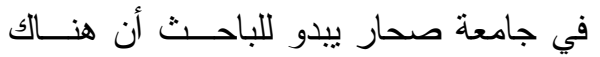
فجوة قائمة بين ما يعرف وما يمسـارس أي ليان

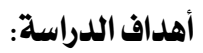
لذا فإن الدر اسة تسعى إلــى تحقيـق بين النظرية و النطبيق فيما يتعلق بارنبــاط لئا

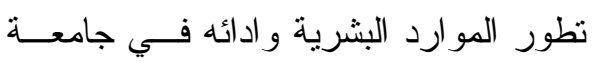
الهدف الرئيس التالي : 
تنتاول موضوع البحث ولعلها تساهم فيما يلي

التعرف على كيفية نطوير الموارد

البشرية بجامعة صحار في ضوء معسايير

• جاءت هذه الدراسة متز امنة مع توجهات

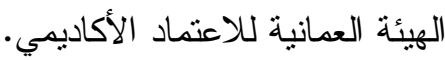

سلطنة عمان في الاهنمام بالموارد

ويتفــرع عـن الهـــف الـــئيس

البشرية. لتحقيق التتمية الوطنية في

الاهداف الفرعية التالية :

مختلف المجالات ، حيث تحتاج السلطنة

إلى مزيد من القوى العاملة الأكثر تعليما

وتخصصيًا لذا حرصت مؤسسات التعليم

العالي على تطوير قدر اتها لتحقيق الجودة

و التميز في مدخلاتها ومخرجاتها .

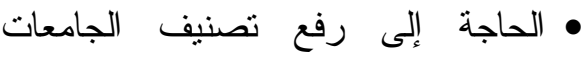

العمانية من خلال تقديم تعليم عالي

الجودة ومطلوب فكرياً ووظيفياً للمحافظة

على موقعها الريادي في نوفير خدمات

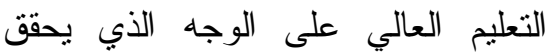

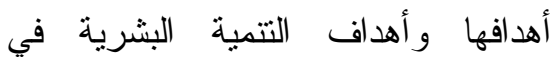

السلطنة .

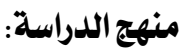

تعتمد الدر اسة الحالية علـى المــنهج

1. التعرف على الإطار الفكري لمعـايير

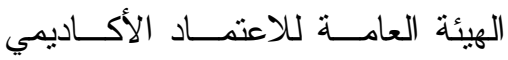

بسلطنة عمان ؟

r. التعرف على الإطار الفكري لعمليــة

تطوير الموارد البشرية ؟

بـ التعرف على و اقع تطـــوير المــوارد

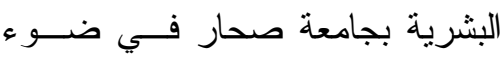

تطبيق معايير الهيئة العمانية للاعتماد

$$
\text { الأكاديمي? }
$$

ع. الكثّف عن وجود اختلاف في و اقــع

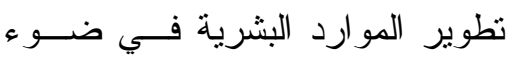

معايير الهيئة العامة العمانية للاعتماد

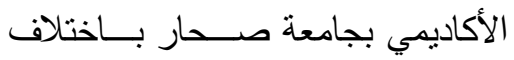

الوصفي فمن خلاله يمكـن التعـرف علــى

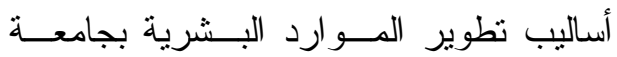

صحار ومدى التزامها بمعايير الهيئة العمانية

للاعتماد الأكاديمي وذللك بما بساعد الباحــث

في تحليل نتائج البحث وتفسير ها و استخلاص

متغير ات الدر اسة .

0. تقديم تصور مقتر ح لتطوير المــوارد

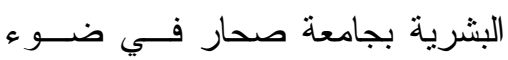

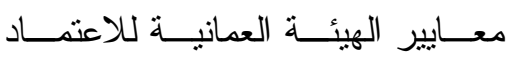

الأكاديمي في سلطنة عمان.

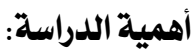

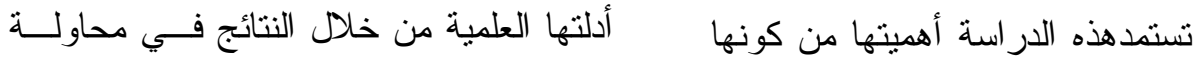

لتعميم الفائدة.

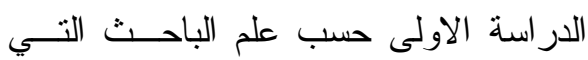


التأهيل و التدريب و التعليم التي تستهدف بهــا

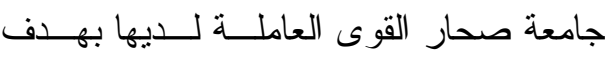
تحسين أداء العمل وجودة الإنتاج.

\section{جامعـــــة صــــــار SUHAR}

UNIVERSITY

خاصة في سلطنة عمــان تقـع فـي و لايــة

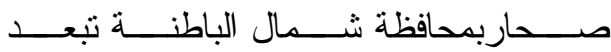
حو الي ·. r. كم شمال العاصمة مسقط تحتوي على كليات منتوعة هي( كلية إدارة الأعمال - كلية الحاسوب وتقنية المعلومات - كليــة التزبية و الآداب - كلية الهندسة - كلية در اسة

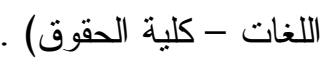

Academic الاعتماد الأكاديمي" Accreditation الإجراءات التي تقوم بها الهيئة العمانية للاعتماد الأكاديمي لتقويم الموارد البشرية لإنجاية بجامعة صحار للتأكد من نوفر الحد الأدنى

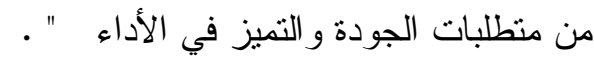

Criteria معايير الاعتماد الاكاديمي "for academic accreditation المو اصفات و الثروط التي لا يمكـن بــدونها

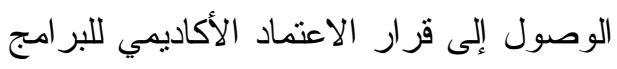

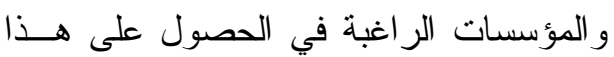
الاعتماد " .

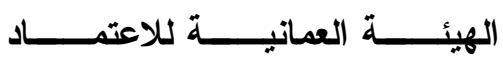

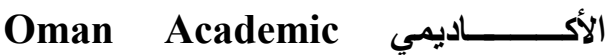
: Accreditation Authority
اقتصرت حدود الدراســـة الحاليــة

و إمكانية تعميم نتائجها على الحدود التالية : الحدود الموضوعية: وتتمثل بتقديم تصور مفترح لتطوير الموارد البشرية في جامعة صحار ومدى التزامها بمعايير الهيئة العمانية للاعنماد الأكاديمي(تخطيط و إدارة الموارد البشرية- خصائص الكادر الوظيفي- التوظيف و الاختيار -الأنشطة التعريفية للموظفين- التطوير الوظيفي- التئيل تخطيط الأداء وتقويمه - الترقيات و الحو افز - انهاء الخدمة - المناخ المؤسسي الهي و استبقاء الموظفين - التعمين ) .

الحدود الجغرافية: وتتمتل في جامعة صحار بسلطنة عمان.

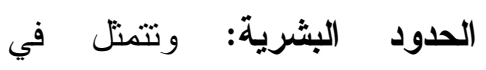
أعضاء هيئة التدريس و الإداريين في جامعة صحار بسلطنة عمان. الحدود الزمنية: طبقت هذه الدراسة

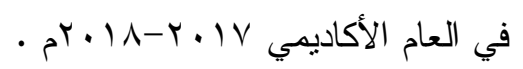

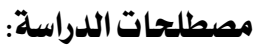
التطوير، يعبر عـن "تحسـسين أداء المو ارد البشرية بجامعة صحار للوصــول لوبير إلى مستوى أفضل في ضوء معايير الهيأـــة العمانية للاعتماد الأكاديمي " . Human المـــوارد البــشرية Resources 
( • ( ) من الذكور و الإناث من (القيادات الإدارية العليا، و الوسطى، و والتتفيذية)

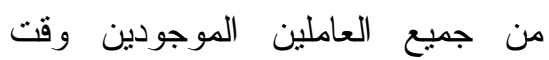
إجراء الاستقصاء في وزارة التربية و التعليم وذلك من خلال المديرية العامة لتتمية الموارد البشرية، ومنطقة الباطنة شمال التعليمية، وكانت الاستبانة أداة

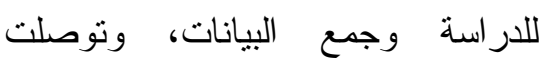
الدر اسة للنتائج التالية : - مجود علاقة طردية موجبة بين كل من بناء خطط وبر امج التعليم المواكبة للثورة العلمية التكنولوجية وبين كفاءة سياسات إدارة الموارد البشرية في مواكبة منطلبات هذه الثورة.

ץ-وجود تفهم من جانب المسئولون بوزارة التربية و التعليم بسلطنة عمان بأهمية بناء

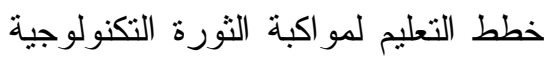
المعاصرة ومحاورها الرئيسة و الوفاء

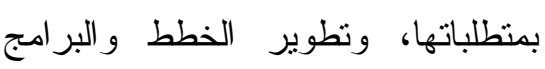
و المناهج التعليمية وفق ونقيز المستجدات التكنولوجية المنطورة.

- توجد علاقة طردية موجبة وقوية بين إعادة صباغة برامج وسياسات إدارة الموارد البشرية مع تضمينها

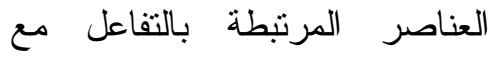
معطيات الثورة العلمية و التكنولوجية
هي مؤسـسة معنيــة بــالترخيص

و الاشتراف والتدقيق على مؤسسات التعلــيم

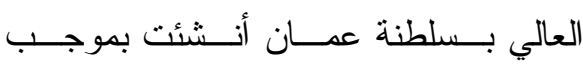

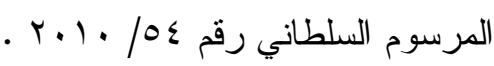

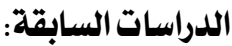

قسم الباحث هذه الدراســات وفــق

ترنيبها الزمنى من الأقدم إلى الأحدث إلــى لــ

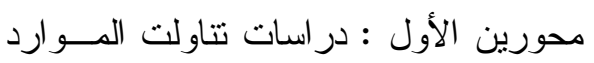

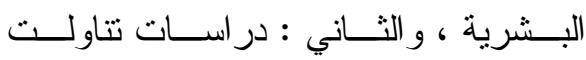

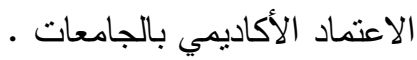

المحور الأول:دراســات ت تناولــــ

$$
\text { الموارد البشرية : المبرد الاول }
$$

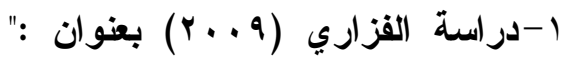

أثز التكنولوجية المعاصرة على تقييم

برامج وسياسات إدارة الموارد

البشرية "تموذج وزارة التربية

والتعليم بسلطنة عمان"، هدفت

الدراسة إلى التعرف على سباسات

إدارة الموارد البشرية، وتحليل برامج إلى

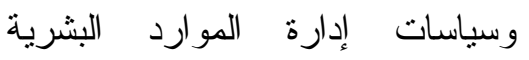

(التعليم - التذريب - البحث العلمي)

في وزارة التزبية والتعليم بسلطنة

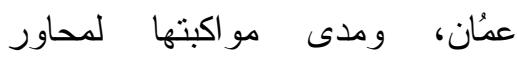

وتحديات التكنولوجية

المعاصرة، واستخدمت الدر اسة المنهج

الوصفي التقويمي باستخدام المسح

الاجتماعي، وتمنل مجتمع الدر اسة في 


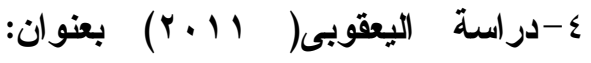
"واقع فاعلية أداء تخطيط الموارد البشرية في ظل التخطيط الاستراتيجي في النظام التربوي بسلطنة عمان"، هدفت الدراسة معرفة و واقع فاعلية تخطيط الموارد البشرية في النظام التربوي بسلطة عمان، وتكونت عينة

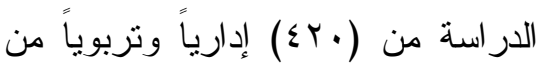
مختلف مناطق السلطنة ولتحقيق أهداف الدراسة قام الباحث بتطوير استبانة

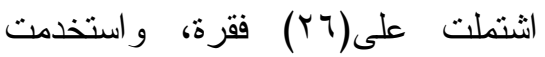
الدراسة المنهج الوصفي، وتوصلت ولتئل الدراسة النتائج التالية : أن هناك وعياً

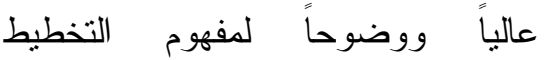

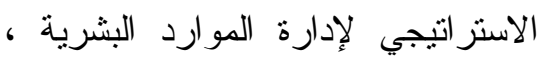

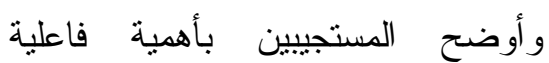
تخطيط الموارد البشرية وارتفاعا في والئ الممارسات الفعلية للتخطيط بين دوائر تتمية الموارد البشرية في النظام التربوي لسلطنة عمان، كما توصلت إلى وجود مجموعة من العوائق التي تحد فاعلية تخطيط المو ارد البشرية جاء في مقدمنها ضعف مستوى المشاركة عند موظفي الوزارة في صياغة أهداف وخطط المو ارد البشرية.
وبين زيادة قدرة وزارة التزبية

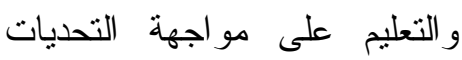

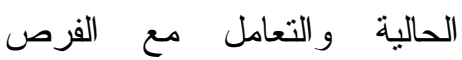
المستقبلية لهذه الثورة.

(soltani, r-دراسة سولتاني وآخرون et., al, 2009) إدارة الموارد البشرية و إدارة الجودة الثاملة في إدارة الأداء: بعض الأدلة"

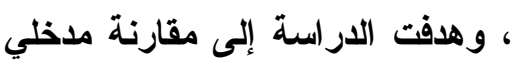
إدارة الموارد البشرية و إدارة الجودة الثاملة لتطوير الأداء، حيث تم إجراء دراسة مسحية لتوفير معلومات حول الوضعية الحالية لتقييم الأداء في منيه منظمات المملكة المتحدة، من خلال الماله التزكيز على فاعلية برامج إدارة الجودة الثاملة، وتوصلت نتائج الدراسة إلى أن إدارة الجودة الثاملة

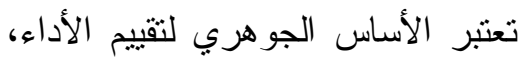
وأن هناك علاقة طردية بين نطبيق

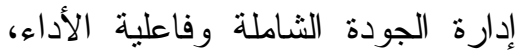
و أن فاعلية بر امج إدارة الجودة الثاملة

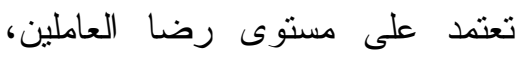
و على الروح المعنوية لديهه، و الثقافة التتظيمية، وأن تحقيق منطلبات نجاح بر امج الجودة يتطلب إعادة التفكير في أساليب تقييم الأداء المتبع في المنظمة. 
Tavid Patton(2015) ب در اسة بعنوان: " مؤشرات الأداء في التعليم

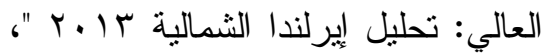
و هدفت الدراسة إلى تقديم ملخص عن

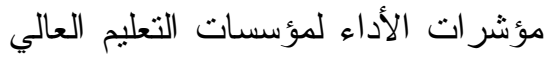

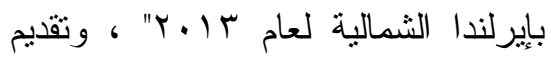
معلومات احصائية جمعها فرع الأبحاث و الإحصائيات في ايرلندا الثمالية عن مؤسسات التعليم العالي وكليات التعليم ،

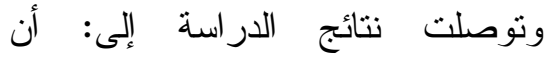
احصائيات مؤشرات الأداء كانت كالتالي لتهات : مشاركة المجموعات صاحبة التمثيل الأقل ، معدلات عدم الاستمرار ل استئناف الدراسة بعد مرور عام ، نتائج التعلم المتوقعة ، الطلاب المستلمين مخصصات الطلاب ذوى الإعاقة .

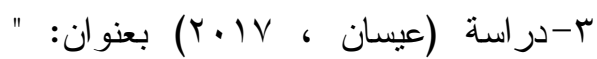
و اقع إدارة الاعتماد البر امجي في جامعة السلطان قابوس"، وهدفت الدراسة إلى

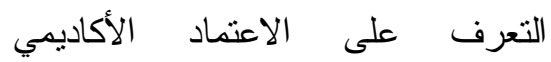
ومعاييره ، و الجهود التي بذلتها جامعة السلطان قابوس للحصول على الاعتماد البرامجي ، وطبقت الدراسة على جميع

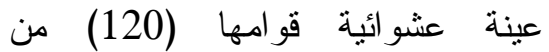
الاكاديميين العاملين في مراكز الجودة

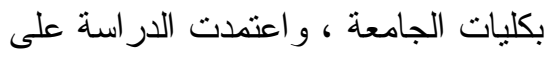

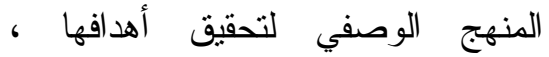

المحور الثاني : دراسات تناولت الاعتماد الأكاديمي :

1-دراسة (الزايدي ، 2014) بعنوان:"

درجة تطبيق معاييز الاعتماد في الجامعات اليمنية الخاصة ومعوقاتها ومقترحات التطوير" ، و هدفت الدراسة إلى التعرف على درجة نطبيق معايير

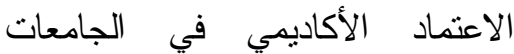
اليمنية الخاصة من وجهة نظر القادة الأكاديميين و والإداريين وتحديد المعوقات التي تحد من نطبيق معايير

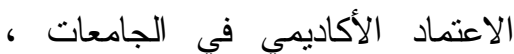
وطبقت الدراسة على عينة مكونة من ، 163) فردا منهم (102 أكاديميا 61 الخاصة، و استخدمت الار اسة استبانة وأسئلة مفتوحة كأداة لتحقيق أهدافها، وتوصلت نتائج الدراسة إلى أن هنالك معوقات تحد من تطبيق معايير

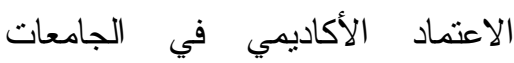
اليمنية الخاصة من أبرزها عدم الإلمام

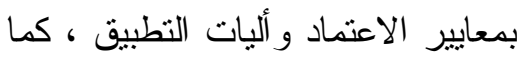

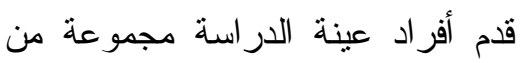
المقترحات لتطوير تطبيق معايير الاعتماد الأكاديمي أبرز ها ثقديم برامج تدريبية وتوعية لنشر نقافة الاعنماد

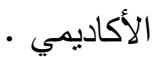


اهتمامها بتطوير الموارد البـشرية بجامعسـة صحار بسلطنة عمُان في ضوء معايير الهيئة العمانية للاعتماد الأكاديمي. الإطار النظري للبحث :

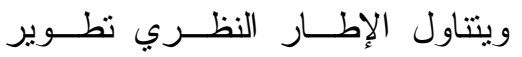

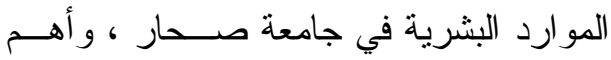
المعايير التي وضعتها الهيئة العمانية للاعتماد الأكاديمي ، وذلك على النحو التالي : أولا : تطوير الموارد البشرية في جامعة ولئ

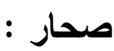

إن الإيقاع الـسريع الــذي فرضــته العولمة على المؤسسات جعل من العالم الكبير

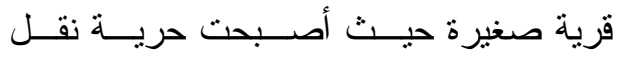

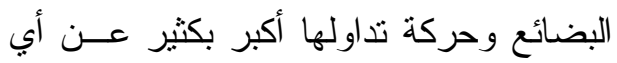
وقت مضى مما جعـل المنظمــات تخطــــ خطو ات واسعة لتتكيف مع الو اقع من خــلدل بناء استر اتيجيات للمو ارد البشرية.

وتهنم استراتيجيات تطوير الموارد

البشرية بالتأكيد على ديمومة المنظمة

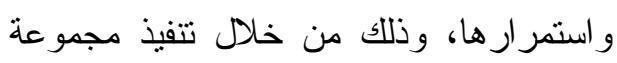

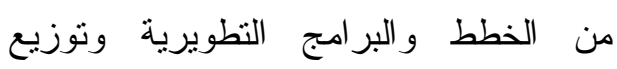

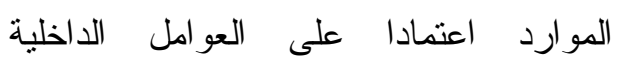
و الخارجية للمنظمة، وكذلك المؤاعمة فيما

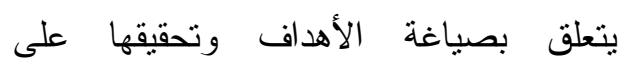
المستوى التنظيمي، وترى الإدارة العليا أن استراتيجيات تطوير الموارد البشرية عملية
وتوصلت نتائج الدراسة إلى أن أهم الدروس العوامل التي ساعدت جامعة السلطان قابوس على حصولها على اعتماد بر امجها الأكاديمية يتمنل في: دعم الإدارة العليا لجامعة السلطان

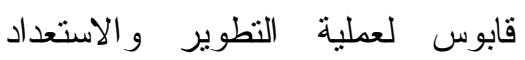

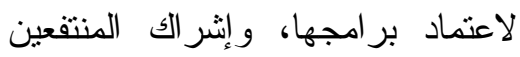
من مخرجات البرامج في عملية وإنرات النظوير ، و والثفافية و الوضوح في في

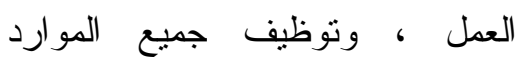
البشرية الأكاديمية بالجامعة . وتئر من خلال عرض الدر اسات الــسابقة يتبين أن بعضها اهنم بتتمية الموارد البشرية في ضوء مدخل إدارة المعرفـــة و الجــودة الثاملة ، بينما ركزت الدراسة الر اهنة على لئ الاهتمام بتطوير المو ارد البشرية في جامعة صحار في ضوء بعـض معسايير الهيئـة العمانية للاعتماد الأكاديمي لإيجاد منظومة لإنة للتققييم تستتد إلى المعايير العالمية لتطـــــير

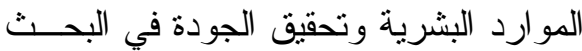

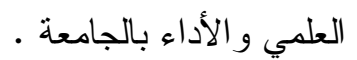

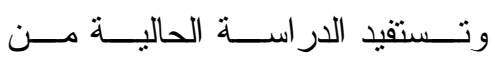

الدراسات السابقة في المزيد من الاطـــلاع

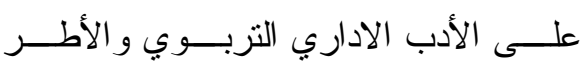
النظرية، و التي قد تساعدها في بناء الإطار

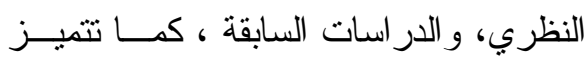
الدراسة الحالية عن الدراسات السابقة فـــي 
الاستر اتيجيات منل استر اتيجية التتوع البشري و الفكري، استر اتيجية التمكين و التعليم المنظمي، استر اتيجية التكيف و التغير المستمر ،استر اتيجية النطور الفني المهاري و الإداري

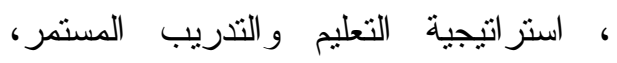

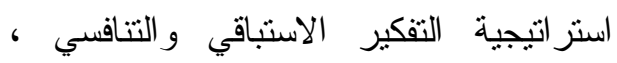
وتساهم هذه الاستر اتيجيات بشكل فعال في تطوير الأداء المؤسسي ومن ثم تحسين قدرة المؤسسات على العطاء ، و هذا عرض لأهم استر اتيجيات تطوير الموارد البشرية : 1-استراتيجية ثقافة التنوع البشرى و القكري:

ارتبطت هذه الاســتر اتيجية بمفهـوم

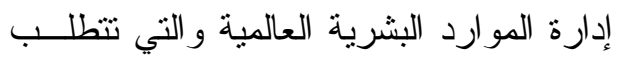
من إدارة الموارد البشرية التوســع فـــي أداء

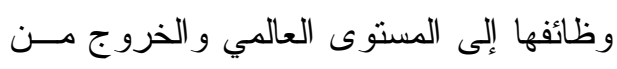

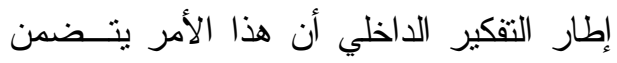

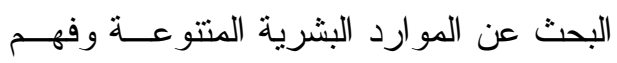
و استيعاب الثقافات المتعددة من خلال التأسيس

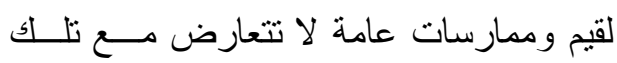

التقافات. (Havvy\&novicevic, 2003). وحتى تتمكن المنظمات من إكتـساب

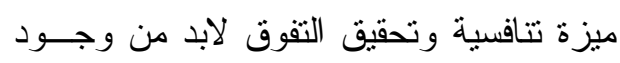

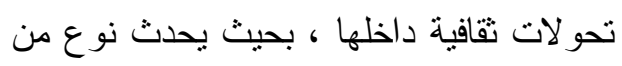
التوحد الثقافي بين ثقافــة المؤسـسـة والإدارة

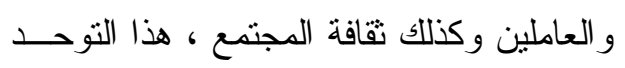
الثقافي يساعد على التأكيد على القيم المشتركة
ذات أهمية لبناء رؤية المنظمة وتطويرها، وتحقيق أهدافها المنبيقة عن استراتيجية الأعمال، الوظائف، و استر اتيجية المنظمة ككل (Stewart \&Goldrick,1996,39). ويمكن تعريف استر اتيجية تطـــوير

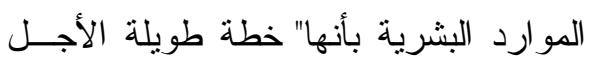
تتكون من مجموعة من النشاطات على هيئة

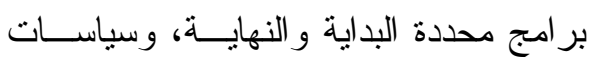

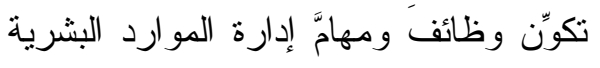
داخل المنظمة، وتحنوي هذه الخطةُ علــى ونى مجموعة من الإجراءات و القرارات المتعلقة

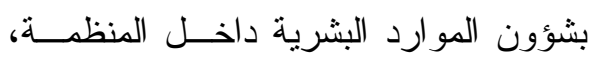

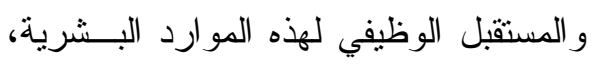

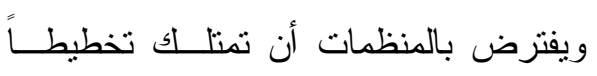
منتظمــاً لمو اردها البشرية، وذلك باختيــار

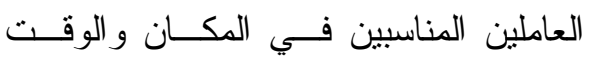

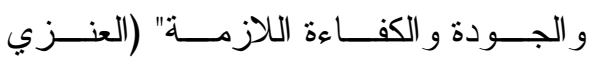

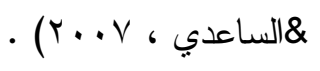

وبناء على الدراسات الأدبية السابقة

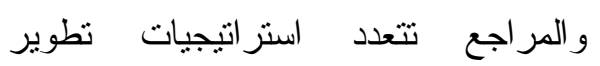
الموارد البشرية طبقا لطبيعة عمل المنظمة ومنها ما يركز على تطوير منظومة القيم

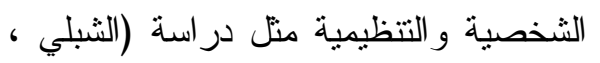

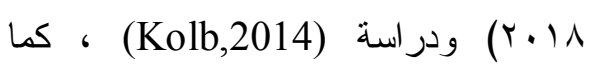

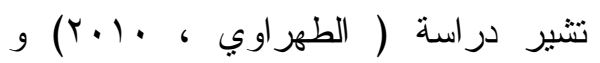
Havvy \& ) ) ( المير، (Y..v) (Novicevic, 2003 
و التطوير و التغيير ، ولعب دورا في عمليــة

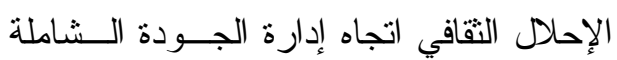

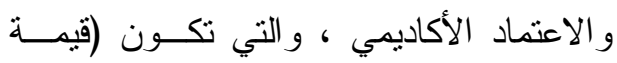
الفعالية) هي قيمتها الإدارية العليا التي يتوحد

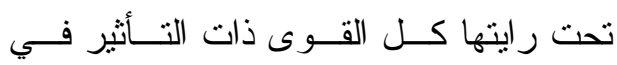

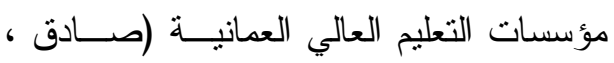
. $0 \leqslant 7: r . .4$ مما سبق يتبين أن الفئة المبحوثة فــي الدراسة الحالية من أعضاء هيئــة التــدريس

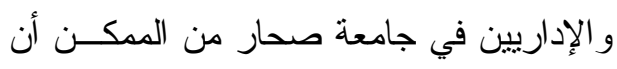

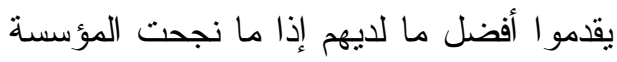
التعليمية في تعزيز انتمائهم لها . ץ-استراتيجية أسلوب التمكين والتعلم المنظمي:

وفقا لهذه الاســتر اتيجية تـسعى إدارة

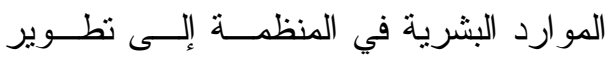
وتتمية الموارد البشرية من خلال المسساهمة

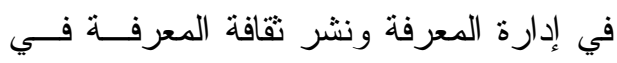
المنظمة، الذي يؤدي إلى تمكـين العـامليين

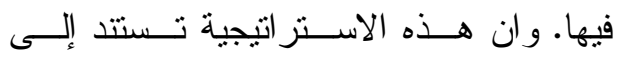

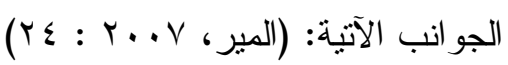

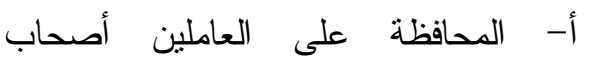
الخبرات الجوهرية ومنحهم الحوافز المشجعة على الاستمر ار ويتم ذلك من خلال توفير واستقطاب الموارد البشرية المتتوعة معرفيا.

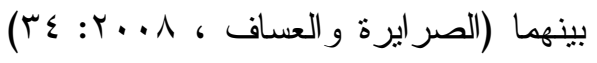
، و عليه فان منظومة القيم الثقافية لمؤسسات

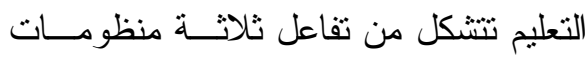
أساسية هي : - - منظومة القيم والتي تعبر عن الثقافة

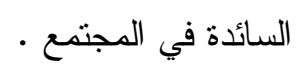
- - منظومة المعارف التي يكتسبها الفرد نتيجة تفاعله المستمر مع بيئته التي بهي تحيط به ، وتثنمل القو اعد و المبادئ

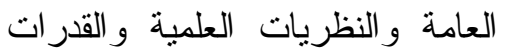
التعليمية التي لابد للموارد البشرية من اكتسابها لتلبية منطلبات الوظيفة في مؤسسات التعليم العالي حنى من من تستطيع تحقيق أهدافها التنظيمية و المتمثلة في جودة المخرجات (Kolb,2014:42) التعليمية

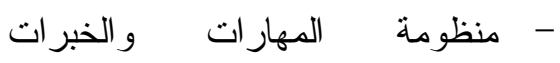
الاجتماعية منل العادات و التقاليد و المهار ات الفنية التي تحكم العلاقات الاجتماعية و المهنية سو اء في الحياة

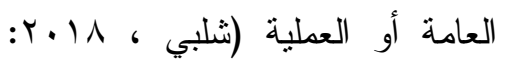
ما سبق من منظومات يتفاعل مــع بعضه البعض ليشكل نسقا عاما يضفي على لئ لئل

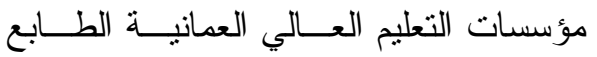

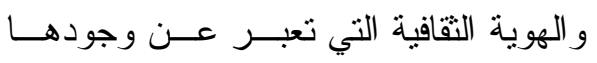

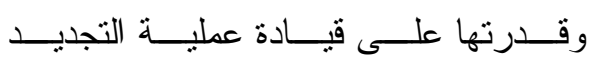


خلال تطــــير قـــــات الأفــر اد و إكـــابهم مهار ات وخبرات ومعارف جديدة تمكنهم من

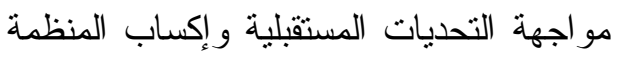

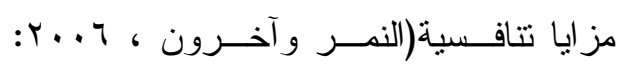
$\cdot(r \leq 7$

ه- استر اتيجية التعليم والتدريب المستمر:

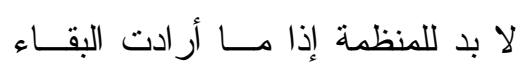

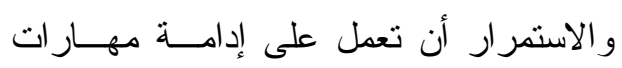

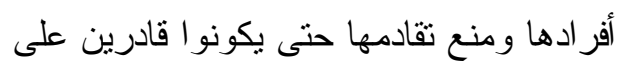

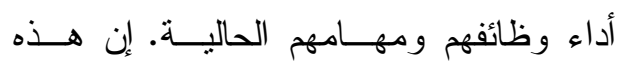
الاستر اتيجية تتطلب من إدارة الموارد البشرية استحداث بر امج تطويرية للعاملين وتمكيـــنهم من القدرة على التكيف و إيجاد برامج التعلــيم و التدريب المستمر ومنح الحو افز التــشيعية.

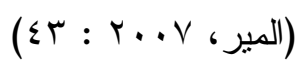

צ- استر اتيجية التفكير الاستباقي والتنافسي: حتى تحقق إدارة المـــوارد البـشرية

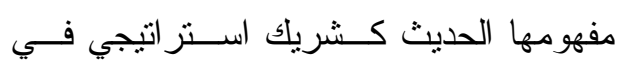
المنظمة لا بد وأن تساعد على تحقيق أهداف

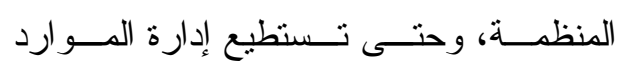

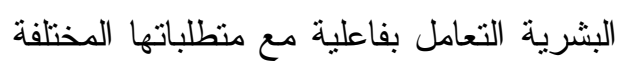

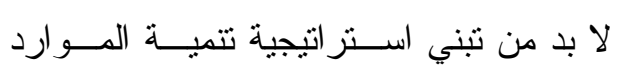

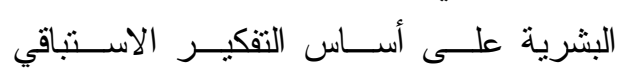

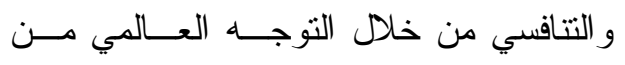

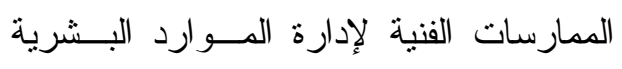

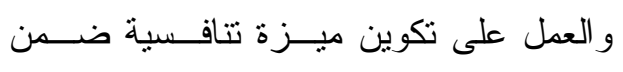

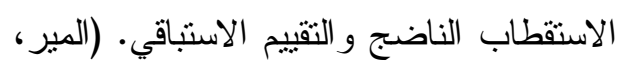
(or: : r...
ب- تعزيز عمليات الابتكــار و الإبـــداع وذللك بنقل القضية بما تتضمنه مــن معرفة كجزء مــن سياســة تتميــة الموارد البشرية و المادية لبناء قاعدة معرفية.

ج - الاستفادة مـن مــصنادر المعرفــة

العالمية، وتنبي فكر عالمي للمـــوارد البشرية، ونظوير فكر عالمي لــدى ولين

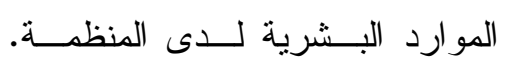

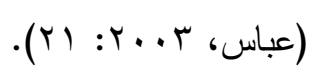

r- استر اتيجية التكيف والتغير المستمر : تبرز أهمية إدارة الموارد البـشرية

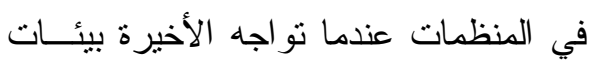

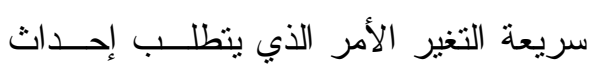

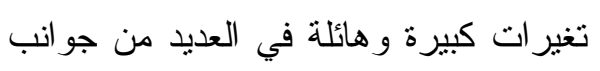

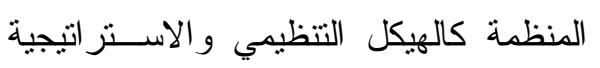
و السياسات و المو ارد البشرية ومن هنا فــان

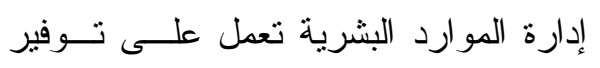
موارد بشرية قادرة على التكيف و إحـــداث التغيرات المطلوبة لمواجهة منل تلك البيئات فضلا عن تصميم الوظائف المختلفة و إعادة

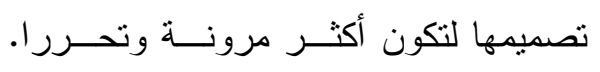

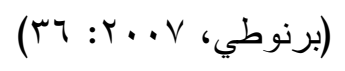
ع - استراتيجية التطور القني والمهارى والإداري: - ميتراتئ

تحرص إدارة الموارد البشرية مــن

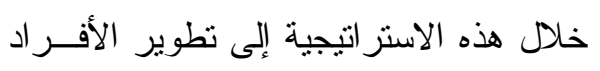

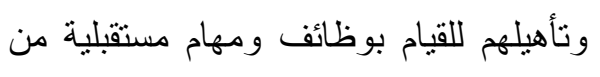


تحسينها عن طريق التدريب والتطوير وفي الوقت ذاته تحديد نقاط الابتكار

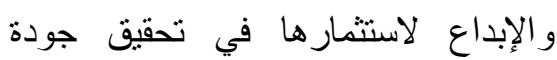

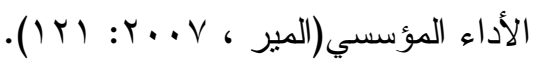

- النطوير المعرفي والمهاري : من خلال الاستثمار في تدريب وتطوير العاملين و إدخال تقتيات و أساليب إدارية لتحسين ونئن الإداء ، وخفض النفقات و العمل على لعل تحديد المعارف و المهارات التي تحتاجها

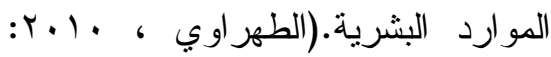
( $\varepsilon$. - نطوير البر امج الدر اسة و الخطط و اعتماد مناهج حديثة تتقق واحتباجات خطط التتمية وسوق العمل ، مع وضع منظومة

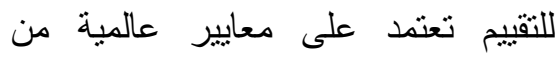

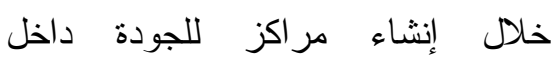
مؤسسات التعليم لحثها على المنافسة وتحقيق معايير الجودة في الأداء و البحث

$$
\text { - العلمي }
$$

ثانيا : المعاييز الأكاديمية العُمانية :

وضعت الهيئـة العمانيــة للاعتمــاد الأكاديمي تسعة معايير يجب أن يتم تبنيها من قبل جميع مؤسسات التعليم العالي في القطاع العام و الخاص في سلطنة عُمان اعنبار ا مــن فئن

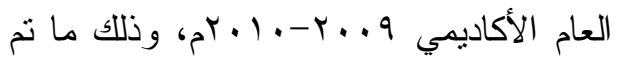

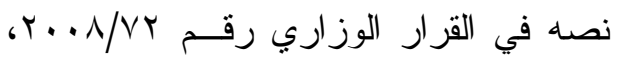

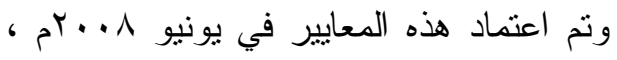

مما سبق يتبن أن هذه الاستر اتيجيات

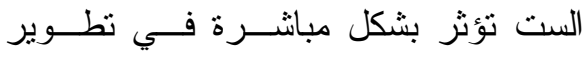
الموارد البشرية وتقدم النشاط البشري فـــي لئري

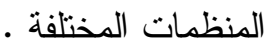

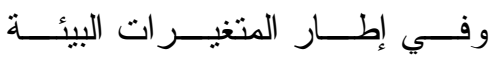
الاقتصادية و الاجتماعية و التكنولوجية كــان

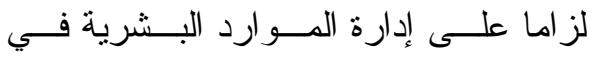

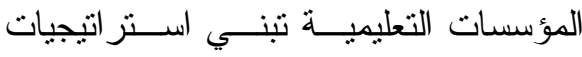
تطويرية قائمة على عدد من القو اعد تتمثتلـل

$$
\text { في الآتي: تفويزلة }
$$

- تمكين العاملين: من خلال تتمية مهار ات العاملين على اتخاذ القرارات الخاصة بأعمالهم ووضع نقافة تتظيمية تشجع على تبني ثقافة خدمة العمل في المقام الأول، وربط المكافآت و الحو افز لفزي بأثكالها المختلفة بالأداء بما بضمن

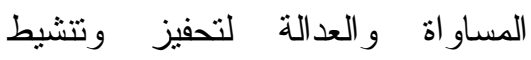
العاملين وغرس قيم الالتزام بأهداف ولفئ

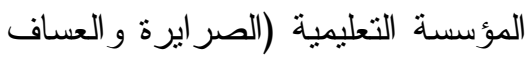
. r. r... ، - اعتماد معايير علمية لقياس الأداء: لكى هـ تتم عملية النطوير المعرفي و المهاري وتحسين وتطوير أداء الموارد البشرية داخل المؤسسة التعليمية لابد من تو افر أليات يتم من خلالها قياس وتقييم أداء العاملين بشكل مهني وعلمي ومستمر يمكن من خلاله تحديد تحديد نقاط التطوير أو التعديل أو التغيير لكي يتم 
و المصادر للعمل على توفير ها (آل مهـدي ، إن . (1): . . द

المعيار الثالث: تعلم الطلبة بطريقة البـرامج الأكاديمية البحثية.

يجب أن تكون لاى المؤسسة التعليمية

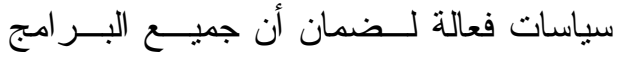
التعليمية فيها نحقق مستويات عاليــة للتعــيم

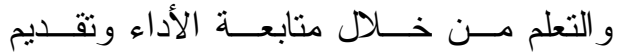
الخدمات المساندة على مسستوى المؤسـسـة

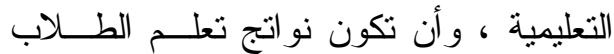

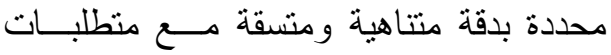
المؤهلات الوطنية و التوظيف ، ومع المعايير

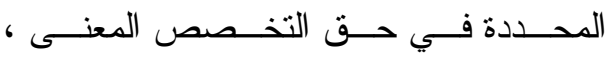

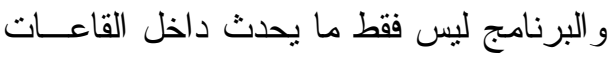

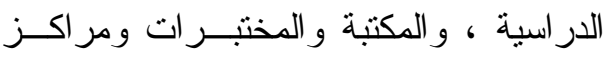

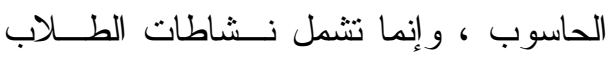
و المحاضر ات و المعارض ، كما أن المنــاهج

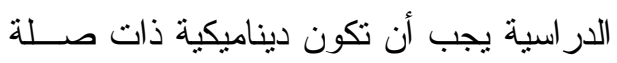
برسالة المؤسسة التعليمية وأهدافها ، وينبغي تلكي

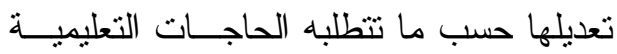

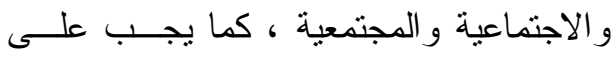
المؤسسة التعليمية أن تحقق توازن بين التعليم

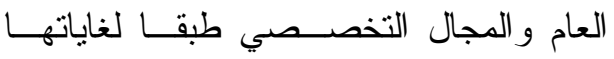
وفلسفتها ، كما يجب أن يكون أعضاء هيئسة التدريس مؤهلين للقبام بمسئولياتهم التنريسية ألتاه ، وأن يشركو ا الطلاب في الأنثطة التنريبية
و هناك تسعة معايير حددتها الهيئة العمانيــة للاعتماد الأكاديمي للنح الاعتماد الأكاديمي للجامعات و الكليات الخاصة بسلطنة عهــان وهي: المعيار الأول: حاكمية المؤسسة و إدارتها: تزويد مؤسـسـات التعلـيم العـالي بالقيادة القادرة على النوجيه و الإدارة بشجع على تحقيق معدلات أفضل للأداء الأكاديمي

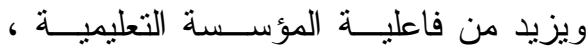
وتتجح المؤسسة في تحقيق هـــا المعيـار

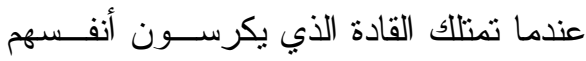

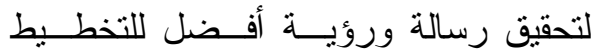
و الإدارة في إطار السياسات والأنظمة التي تضمن تحقيق المساعلة الإدارية و الماليــة ،

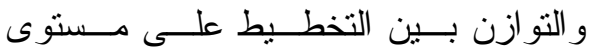

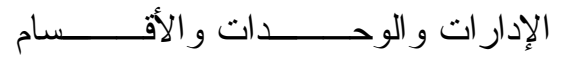
. (www.oaaa.gov.om) المعيار الثــاني: تعـــم الطلبــة بطريقــة المقررات الدراسية ومصادر التطلم : يجب على المؤسسات التعليميــة أن تخطط لمصادر التعلم ويشمل ذلك المكتبات

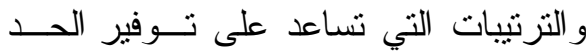

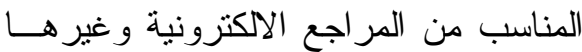

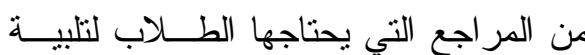

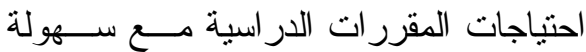
الوصول إليها ، ويجب على أعضاء هيئـــة

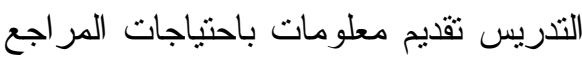




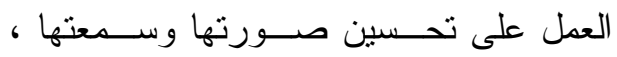

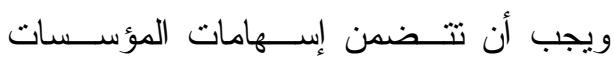

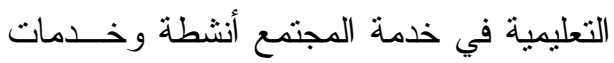

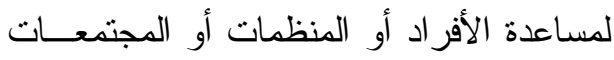

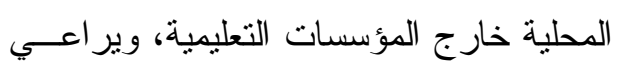
أن لا تدرج ضمن الاسهامات المتوقعة مــن

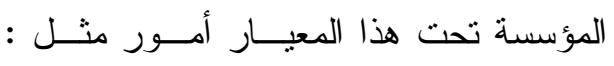
المساعدات المالية ، الأنشطة الطلابية ، تقديم

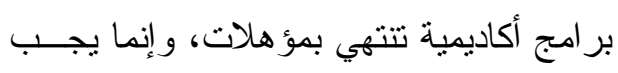
أن تتضمن المشاركة في المـشـاريع البحثيـــة و النطويرية ، وفي بر امج التعليم المجتمعي لنئي

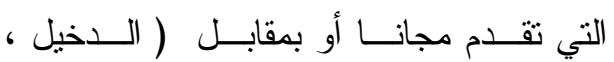

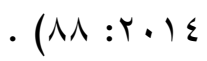

كما يجب على مؤسسات التعليم العالي

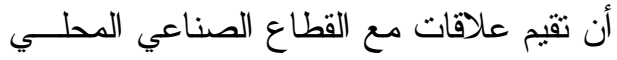
وأرباب الأعمال حيث تساعد هذه العلاقــات على تقديم بر امج ودور ات تخــدم اهتمامــات الفرد و المجتمع ، كمـــا تـسمح المؤســسات

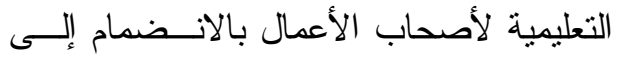

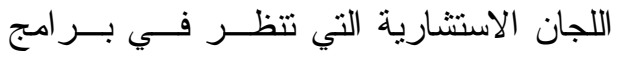

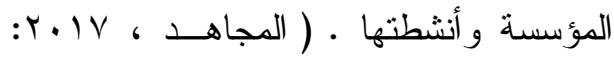
- (VT

المعيار السادس: خدمات الدعم الأكاديمي :

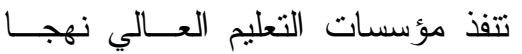

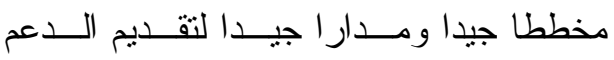

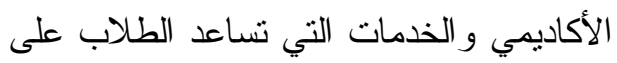
تحقيق أهدافهم التعليمية. منل خدمة الإرشــاد
لتحسين كفاءاتهم.(www.oaaa.gov.om)

المعيــار الرابـــع : أبحـــاث الأكـــــيميين

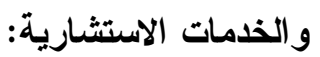

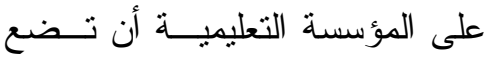
استز اتيجية للبحث العلمي تتفق مع رســالتها وطبيعتها ، وأن يشارك جميع أعضاء الهيئة

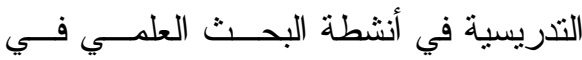

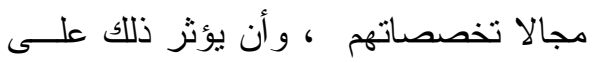

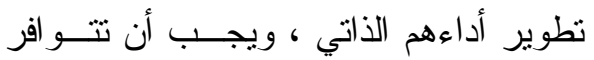

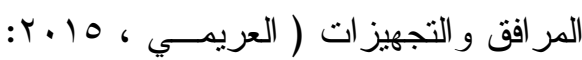

المعيار الخامس: المشـاركة في المجتمــع المحلي و القطاع الصناعي :

يجب النظر إلى المشاركة في خدمة المجتمع المحلي بصفتها مسئولية مهمة من لن مسئوليات مؤسسات التعليم الجامعي ، و وأن تتو افر الخدمات و المر افق لــدعم عمليــات تطوير المجتمع ، لذا يجب تشجيع أعـضاء

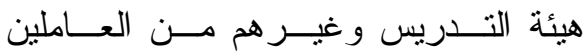
بالمؤسسات التعليمية على المـشاركة فـي

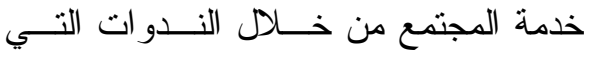

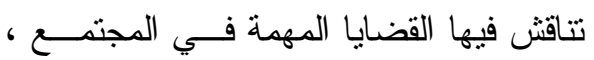
وأن تكون المعلومــات عـن المؤسـسات التعليمية و أنشطتها معروفــة ، ويجــبـ أن أن

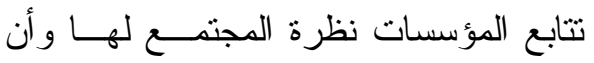
تتبنى الاستر اتيجيات المناسـبة مــن أجـل لــل 
القبول والتسجيل لها دور كبير فــي إطـــلاع

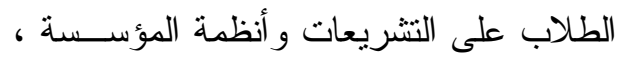

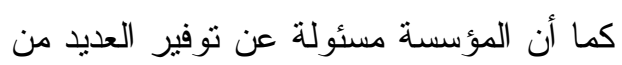

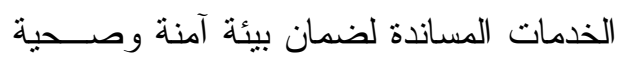

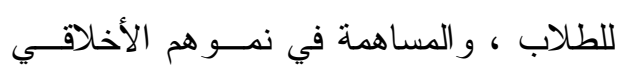
و الثقافي و الجسدي ، وتختلف نوعية الخدمات الطلابية من مؤسسة إلى أخرى طبقا لطبيعتها

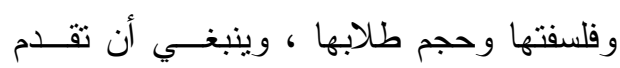

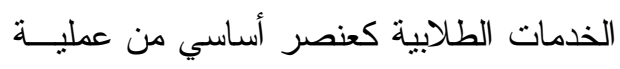
التدريس، كما ينبغي نشر الخدمات الطلابيـــة بشكل كافي وخضوعها للتقييم بانتظام و العمل على تحسينها كجزء مــن عمليــة الاعتمـاد

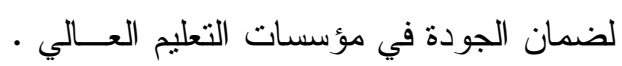

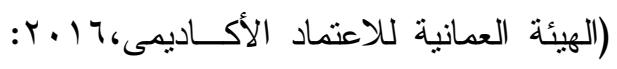

المعيار الثامن: الموظفون وخدمات الــــمم

\section{الوظيفي:}

جاء المعيار الثامن متماشيا مع الإطار

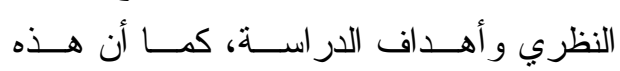

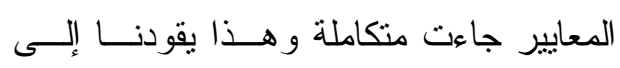
التعرّت على مبررات تطبيق المعيار الثـامن دون غيره حيث يتضح ذلك من العرض الآتي

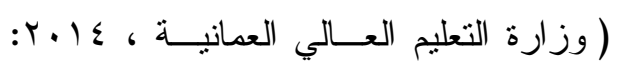
$:(r \cdot)$

() تتابع المتغيرات العالمية المعاصرة، و التي تؤثر في جودة أداء الموظف ومنها: التقدّم العلمي، تقدم التقنيات و الاتصالات، الثورة الثورة الاقتصادية.
الأكاديمي في الجامعة ودعمهـــا التعليمــي ومواردها التعليمية يمكن الوصــول إليهــــا

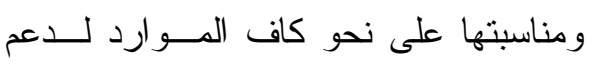

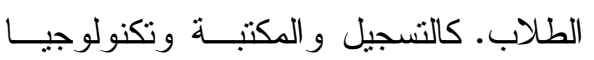

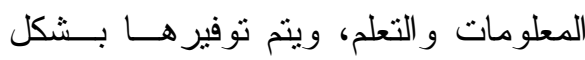

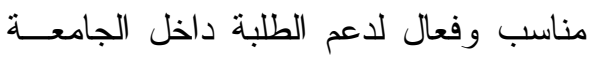
و أنشطة البحث العلمي.

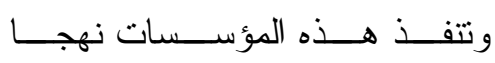

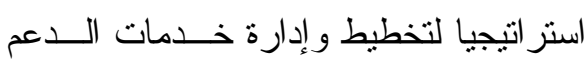
الأكاديمي و التي تتمانشى مع مهمتها، وتوفير وإنير

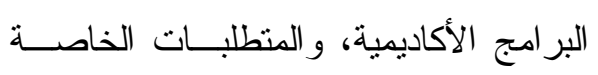
بالطلاب. ويــتم تـــوفير المـــوارد الكافيــة لخدمات الدعم الأكاديمي ورصدها بانتظـــام

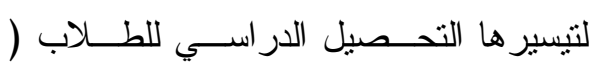

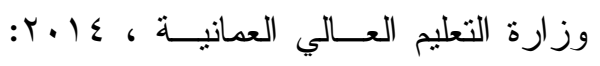

ويتكون المعيار من ســبع أجـز اء

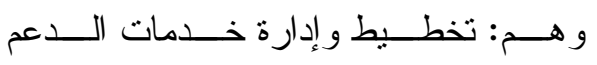

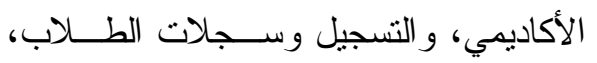

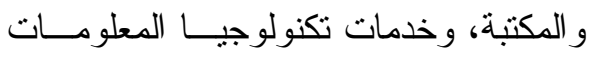

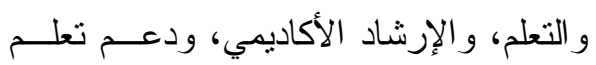

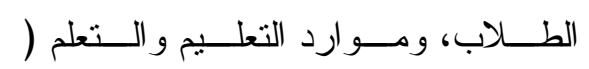
.(http://www.oaaa.gov.om المعيار السابع: الطلبة وخــدمات الــــمم الطلابي: إن نظم إدارة الطلاب ، وخــدمات

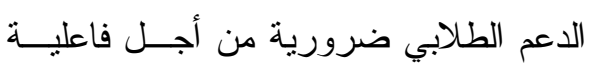

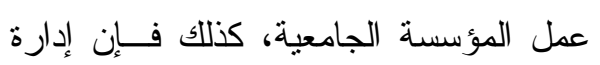


وقد اشتمل هذا المعيــار علـى عـدة

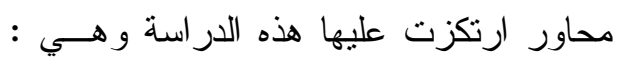

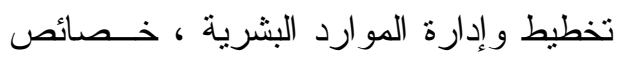

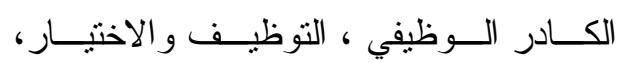

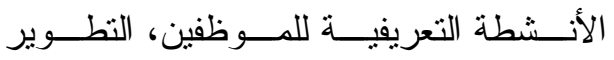
الوظيفي ، تخطيط الأداء وتقويمه ، التزقيات

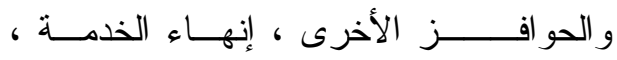

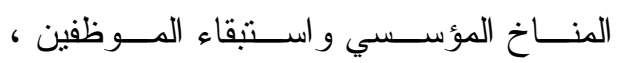

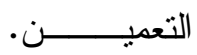

المعيار التاسع: خدمات الدعم العامة (قــــــار مجلس التعليم العالي رقم ب/ ب/ . . r):

وبتحليل هذه المعايير ومدى ارتباطها

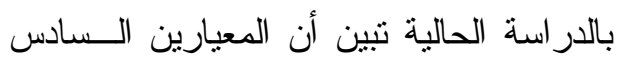

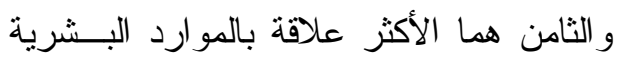
لذللك تم تحليل كل منهما على حدة حيث تبين

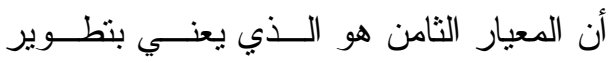

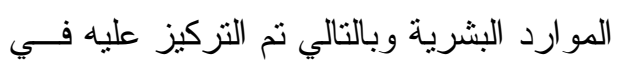
الاسنبيان كما سيتضح لاحقا.

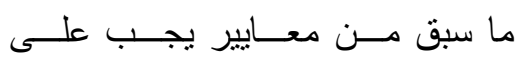

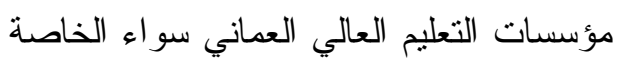

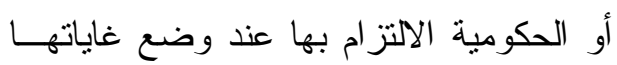

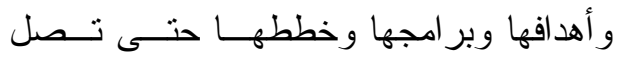
لمستوى يقارب المعايير الدولية فــي تقــــيم

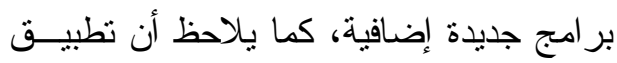
معايير الاعتماد يعتمد على العنصر البـشري

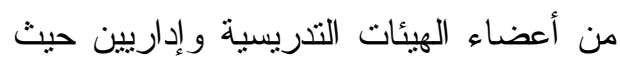
يقع على عاتقهم مسئوليات ومهام جسام مسن أنس

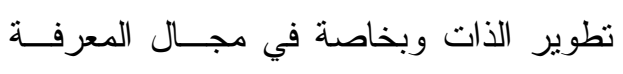

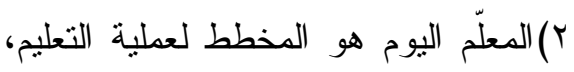

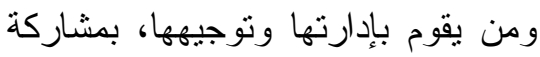

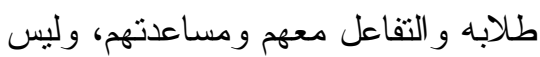

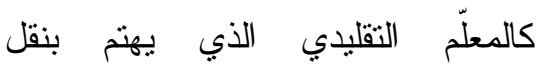
المعلومات وتلقينها للطلاب.

r)تزيد من وعي الموظفين بمفهوم الجودة و أساليبها و أهدافها، ومنطلبات تطبيقهـ

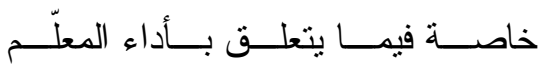

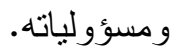
ع)تحسين دافعية الموظف بشكل عام نحــو

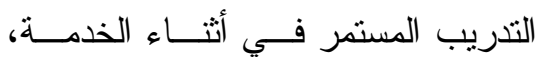

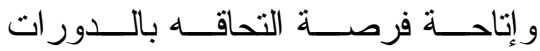
التدريبية المتخصــصة، وورش العمـلـل

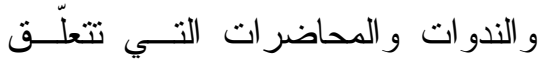
بتخصصد، أو بتطوير أدائه وتحسينه. 0) الكثف عن فاعليّة الموظف، واتجاهـــ

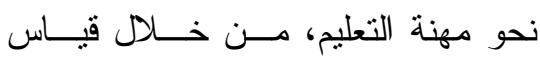
الأداء. 7) العمل على رفع مستوى كفاية الموظف شخصياً و علمياً و مهنياً و اجتماعياً.

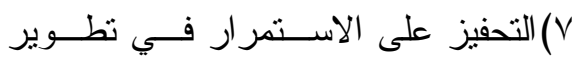
الأداء، ورفع الكفاية الإنتاجية للموظفين.

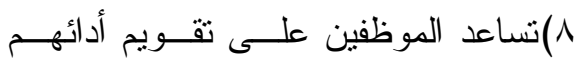

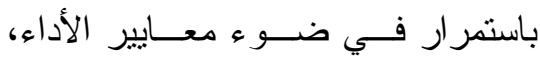

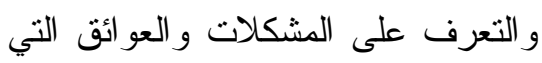
تعترض تقدمهم، و العمل على تنافيهـا

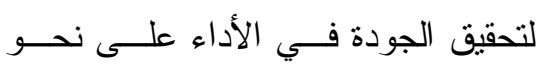




$$
\text { و البحث العلمي لــذا نجــــ أن الجامعــات الدراسـة الميدانيـة: }
$$

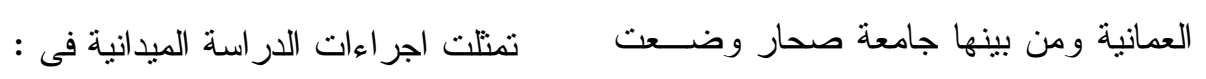

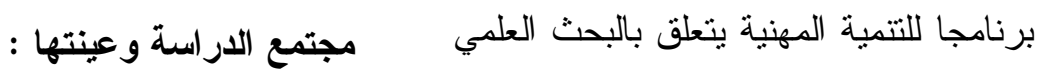

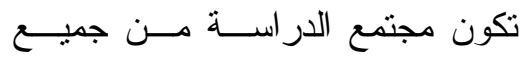

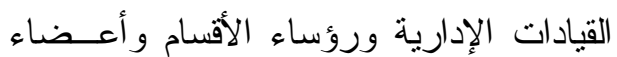

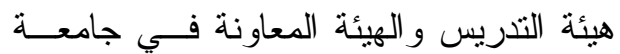

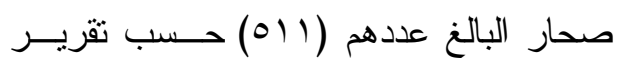

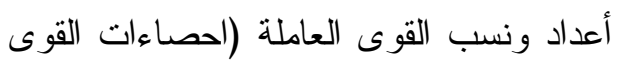

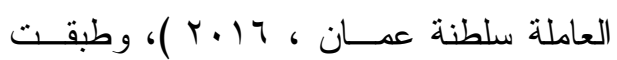

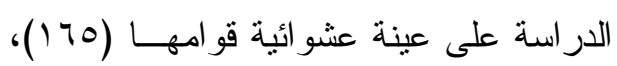
و الجدول التالي يوضح توصيف عينة الدراسة

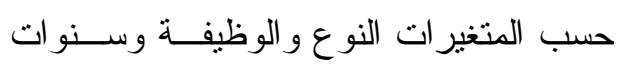

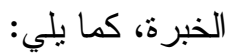

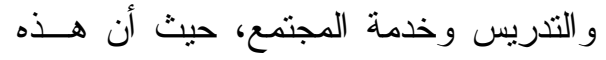
البر امج من شأنها أن ترفع كفاية عضو هيئة

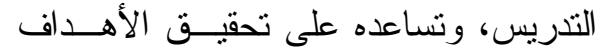
المنشودة للعملية التعليمية، بالإضــافة إلـى الـى الـى

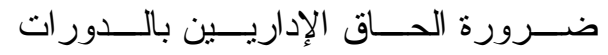

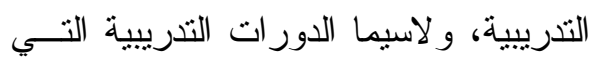

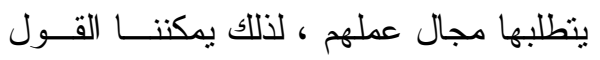
بأن التطلع إلى الجودة الــشاملة و الاعتمــاد

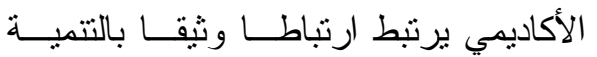
المهنية للموارد البشرية مسن الأكساديميين

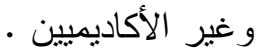

جدول (1)

توصيف عينة الدراسة حسب متغير النوع

\begin{tabular}{|c|c|c|c|}
\hline النسبة & العينة & تيرات الدر اسة & \multirow{3}{*}{ النوع } \\
\hline$\% \circ \vee, 7$ & 90 & ذكور & \\
\hline$\% \varepsilon r, \varepsilon$ & v. & إناث & \\
\hline$\% 1 \ldots$ & 170 & \multicolumn{2}{|l|}{ الإجمالي } \\
\hline$\% \backslash 7,\{$ & rV & مدير & \multirow{5}{*}{ 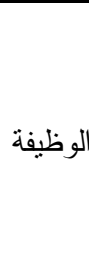 } \\
\hline$\% r,, r$ & ro & رئيس قسم & \\
\hline$\%$ \%ч, т & $\varepsilon \varepsilon$ & 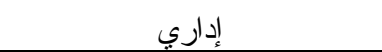 & \\
\hline$\% 10, r$ & ro & باحث & \\
\hline$\% r \cdot, \uparrow$ & $r \varepsilon$ & عضو هيئة تدربس & \\
\hline$\% 1 \ldots$ & 170 & \multicolumn{2}{|l|}{ الإجمالي } \\
\hline$\% r r, q$ & $\leq 7$ & أقل من [ 0 ] سنو ات & \multirow{3}{*}{ الخبرة } \\
\hline$\% \varepsilon 1, r$ & 71 & من [0] إلى أقل من [ • 1]] سنو ات & \\
\hline$\%$ \%, , & 01 & أكثر من [ [ 1 ] سنوات & \\
\hline$\% 1 \ldots$ & 170 & \multicolumn{2}{|l|}{ الإجمالي } \\
\hline
\end{tabular}


العمانية للاعنماد الأكاديمي وذلك بهدف صياغة محاور الاستبانة.

ب- تم عرض الاســنبانة فـي صــورتها الأولية على المشرفين وهي مكونة من عـشرة محاورتــشتمل علــى ثمــاني وخمسين مفردة ، وكانت بدائل الاجابة مرتبة وفقا لمقياس ليكرت(عالية جدا ، عالية، متوسطة ، منخفضة ، منخفضة

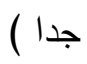

ج • نم عرض الاســتبانة عــى الــسادة

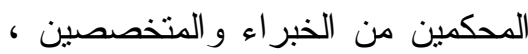
وذلـــك للتحقــق مــن مــــى ارتبـــاط

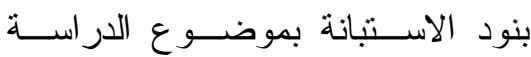

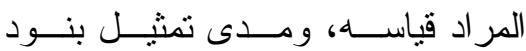
الاستبانة وشمولها لمحتــوى الدراســة

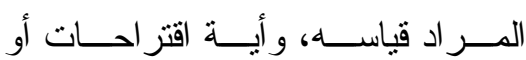
تعديلات مناسبة لتحقيق هدف الدر اســـة

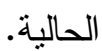
د . في ضو ء اقتر احسـات بعـض الــسادة المحكمين أجرى الباحــث التعـديلات المناسبة حيث تم حذف و إعادة صياغة

$$
\text { بعض العبار ات . }
$$

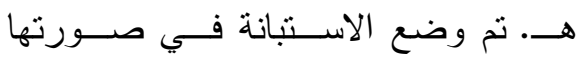

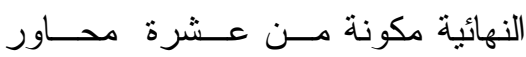
رئيسة:
مــن الجــدول الــسابق: يتــــح أن

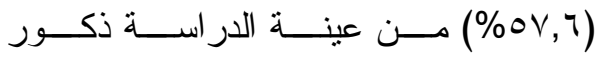

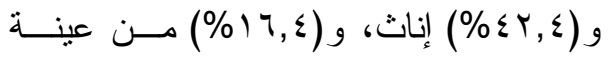

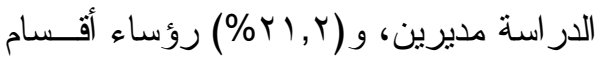

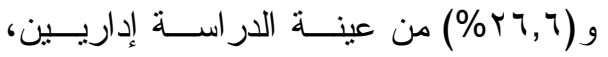

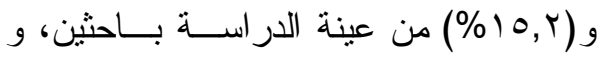

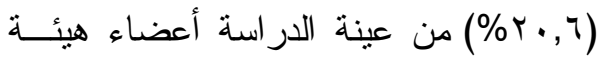

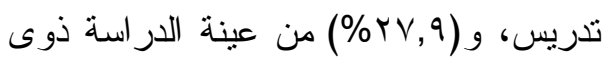

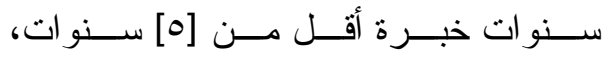

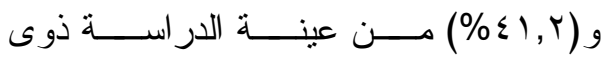

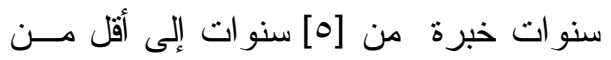

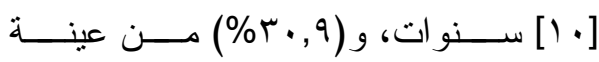
الدراسة ذوى سنوات خبرة أكثر مـن [ • 1]

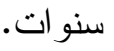

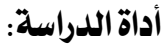

لتحقيق أهــــاف الدراســـة الميدانيــة صــمم الباحسـث اســتبانة موجـــه للهيئـــة

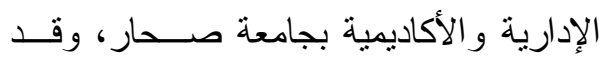

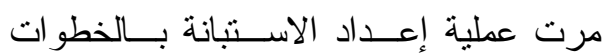
الآتية:

أ- قام الباحث بالاطلاع علــى الدر اســات و البحوث السابقة ذات الصلة بموضوع الدر اسة و الاطلاع على الإطار الفكري لعملية تطوير الموارد البشرية بجامعسـة صحار، وواقع تطوير الموارد البشرية بجامعة صحار في ضوء معايير الهيئة 
محكم للتأكد من أن الاستبانة تقيس ما

استخدمت لقياسه. وقد تم تعـديل مـــا

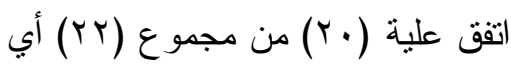

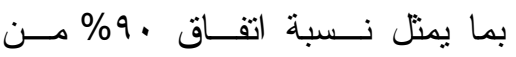

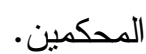

• مؤشر صدق التكوين (الاتساق الداخلي):

وتم حساب صدق الاتساق الــداخلي

للاستبانة بعد تطبيقها على عينــة عـشـوائية

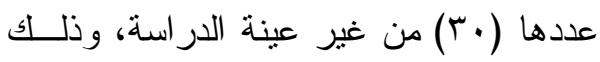

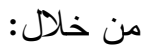

• ارتباط درجة كل مفردة بالارجة الكلية

للمحور المنتمية إليه: تم حساب معاملات

ارتباط درجة كل مفردة بالدرجة الكلية

للمحور الذي تتنمي إليه، وجاءت النتائج

كما هي مبينة بالجداول التالية:
صدق وثبات أداة الار اسة الميدانية :

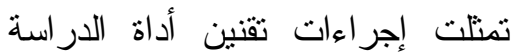

$$
\text { فيما يلي: }
$$

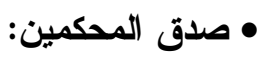

وللتأكد من مدى صلاحية هـذه الأداة

للتطبيق قام الباحث بحسـساب صــدق وثبــات الاسنبانة ونلك كالتالي:

(أ) حساب صدق الاســتبانة: ويعنـى أن

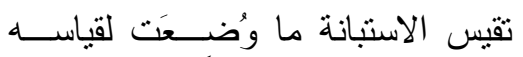

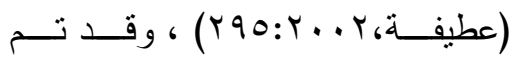

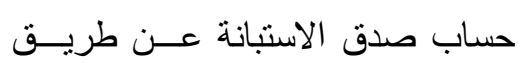

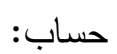

صدق المحكمين( الــصدق الظـاهري ):

للتحقق من صدق الاستبانة نم عرضها

على عدد مــن المتخصــصنين مـنـ

أعضاء هيئة التذريس وعددهم (r) 


\section{جدول (ץ)}

قيم معاملات ارتباط درجة كل مفردة الاستبانة بالارجة الكلية للمحاور التي تتنمى إليه

\begin{tabular}{|c|c|c|c|c|c|c|c|}
\hline مستوي الدلائي & الارتباط & المفردة رقم & المجال & الدستوية & الارتباط & المفردة رقم & المجال \\
\hline$\cdot, \cdot 1$ & $\cdot, \wedge \vee \top$ & 0 & التطوير الوظيفي & $\cdot, \cdot 1$ & $\cdot, 9$ & 1 & \multirow{6}{*}{ المو ارديط البشرية إدارة } \\
\hline$\cdot, \cdot 1$ & $\cdot, \wedge T 1$ & 1 & \multirow{7}{*}{ تخطيط الأداء } & $\cdot, \cdot 1$ & $\cdot, 91$ & $r$ & \\
\hline$\cdot, \cdot 1$ & $\cdot, \wedge Y_{1}$ & $r$ & & $\cdot, \cdot 1$ & $\cdot, \Lambda \mid r$ & $r$ & \\
\hline$\cdot, \cdot 1$ & $\cdot, \Lambda \mid Y$ & $r$ & & $\cdot, \cdot 1$ &., 099 & $\varepsilon$ & \\
\hline$\cdot, \cdot 1$ & $\cdot, \wedge 11$ & $\varepsilon$ & & $\cdot, \cdot 1$ & $\cdot, \wedge \mid \leq$ & 0 & \\
\hline$\cdot, \cdot 1$ & $\cdot, \wedge \wedge 1$ & 0 & & $\cdot, \cdot 1$ & $\cdot, 107$ & 7 & \\
\hline$\cdot, \cdot 1$ & $\cdot, \wedge \uparrow$ & 7 & & $\cdot, \cdot 1$ & $\cdot, \wedge 10$ & 1 & \multirow{6}{*}{ خصائص الكادر } \\
\hline$\cdot, \cdot 1$ & $\cdot, 107$ & v & & $\cdot, \cdot 1$ & $\cdot, \wedge 01$ & $r$ & \\
\hline$\cdot, \cdot 1$ & $\cdot, 9$ & 1 & \multirow{5}{*}{ و الحو أفرقيات } & $\cdot, \cdot 1$ & $\cdot, \wedge 10$ & $r$ & \\
\hline$\cdot, \cdot 1$ & $\cdot, 9.9$ & $r$ & & $\cdot, \cdot 1$ & $\cdot, V Y O$ & $\varepsilon$ & \\
\hline$\cdot, \cdot 1$ & $\cdot, \vee \vee 99$ & $r$ & & $\cdot, \cdot 1$ & $\cdot, T / Y$ & 0 & \\
\hline$\cdot, \cdot 1$ & $\cdot, \wedge \vee \mu$ & $\varepsilon$ & & $\cdot, \cdot 1$ & $\cdot, \mathrm{VT}$ & 7 & \\
\hline$\cdot, \cdot 1$ & $\cdot, 100$ & 0 & & $\cdot, \cdot 1$ & $\cdot, 7 \wedge \varepsilon$ & 1 & \multirow{8}{*}{ و الاختيبار } \\
\hline$\cdot, \cdot 1$ & $\cdot, 170$ & 1 & \multirow{5}{*}{ إنهاء الخدمة } & $\cdot, \cdot 1$ & $\cdot, \wedge \leqslant 0$ & $r$ & \\
\hline$\cdot, \cdot 1$ & $\cdot, 107$ & $r$ & & $\cdot, \cdot 1$ & $\cdot, \vee \vee \wedge O$ & $r$ & \\
\hline$\cdot, \cdot 1$ & $\cdot, 119$ & $r$ & & $\cdot, \cdot 1$ & $\cdot, \lambda r$ & $\varepsilon$ & \\
\hline$\cdot, \cdot 1$ & $\cdot, \mathrm{V} 9 \mathrm{r}$ & $\varepsilon$ & & $\cdot, \cdot 1$ & $\cdot, \wedge \vee \Gamma$ & 0 & \\
\hline$\cdot, \cdot 1$ & $\cdot, \wedge 0 \wedge$ & 0 & & $\cdot, \cdot 1$ & - , vor & 7 & \\
\hline$\cdot, \cdot 1$ & $\cdot, \vee \wedge \vee \vee$ & 1 & \multirow{7}{*}{ المناخ المؤستسي } & $\cdot, \cdot 1$ & $\cdot, \wedge$ Y O & v & \\
\hline$\cdot, \cdot 1$ & $\cdot, \wedge r r$ & $r$ & & $\cdot, \cdot 1$ & $\cdot, \wedge r$ & $\Lambda$ & \\
\hline$\cdot, \cdot 1$ & $\cdot, \wedge 0 \leqslant$ & $r$ & & $\cdot, \cdot 1$ & $\cdot, \wedge \vee q$ & 1 & \multirow{5}{*}{ للموظفينة الأنشية } \\
\hline$\cdot, \cdot 1$ & $\cdot, \wedge \leq 9$ & $\varepsilon$ & & $\cdot, \cdot 1$ & $\cdot$, , ० & $r$ & \\
\hline$\cdot, \cdot 1$ & $\cdot, \wedge \cdot 0$ & 0 & & $\cdot, \cdot 1$ & $\cdot, \wedge \circ \wedge$ & $r$ & \\
\hline$\cdot, \cdot 1$ & $\cdot, \wedge \backslash 1$ & 7 & & $\cdot, \cdot 1$ & $\cdot, \vee \vee \vee 1$ & $\varepsilon$ & \\
\hline$\cdot, \cdot 1$ & $\cdot, \wedge 0 \wedge$ & V & & $\cdot, \cdot 1$ & •, & 0 & \\
\hline$\cdot, \cdot 1$ & $\cdot, \wedge \wedge 0$ & 1 & \multirow{4}{*}{ التعميــــــن } & $\cdot, \cdot 1$ & $\cdot, \wedge r q$ & 1 & \multirow{4}{*}{ الوظيفي } \\
\hline$\cdot, \cdot 1$ & $\cdot, \wedge \vee q$ & $r$ & & $\cdot, \cdot 1$ & $\cdot, \wedge \wedge \uparrow$ & $r$ & \\
\hline$\cdot, \cdot 1$ & $\cdot, \wedge \vee q$ & $r$ & & $\cdot, \cdot 1$ & $\cdot, \wedge r r$ & $r$ & \\
\hline$\cdot, \cdot 1$ & $\cdot, \wedge r q$ & $\varepsilon$ & & $\cdot, \cdot 1$ & $\cdot, \wedge \neg \leq$ & $\varepsilon$ & \\
\hline
\end{tabular}

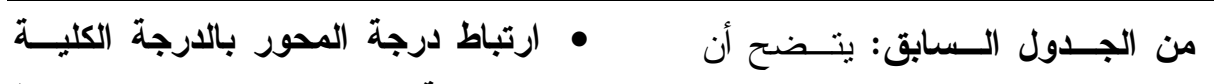

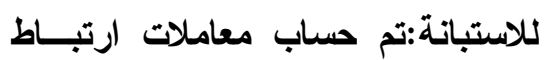

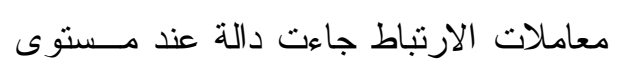

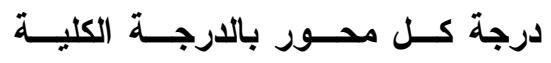

للاستبانة،وجاءت النتائج كما هي مبينة

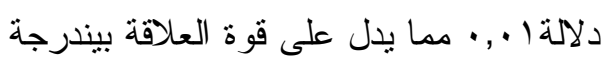

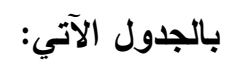

مفردات الاستبانة و المحاور التي تتتمي إلبها. 
جدول (r) قيم معاملات ارتباط درجة كل محور بالدرجة الكلية للاستباتة، ومستوى الدلالة

\begin{tabular}{|c|c|c|c|}
\hline مستوى الالالة & معامل ارتباط & المحاور & م \\
\hline$\cdot, \cdot 1$ &., $9 \mathrm{rV}$ & تخطيط و إدارة الموارد البشرية & 1 \\
\hline$\cdot, \cdot 1$ & $\cdot, 94$ & خصائص الكادر الوظيفي & r \\
\hline$\cdot, \cdot 1$ & $\cdot, 9 \pi \leq$ & التوظيف و الاختيار & r \\
\hline$\cdot, \cdot 1$ & $\cdot, 90$ & الأنشطة التعريفية للموظفين & $\varepsilon$ \\
\hline$\cdot, \cdot 1$ & $\cdot, 9 \vee Y$ & التطوير الوظيفي & 0 \\
\hline$\cdot, \cdot 1$ & $\cdot, 90 \mathrm{r}$ & تخطيط الأداء وتقويمه & 7 \\
\hline$\cdot, \cdot 1$ & $\cdot, 9 \leq 0$ & التزرقيات و الحو افـــــــز الأخرى & $\mathrm{V}$ \\
\hline$\cdot, \cdot 1$ & $\cdot, 9 \Gamma 0$ & إنهاء الخدمة & $\wedge$ \\
\hline$\cdot, \cdot 1$ & $\cdot, 9 Y 1$ & المناخ المؤسسي و استبقاء الموظفين & 9 \\
\hline$\cdot, \cdot 1$ & $\cdot, 9 Y 1$ & التعميـــــــن & 1 . \\
\hline
\end{tabular}

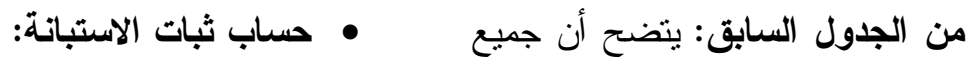

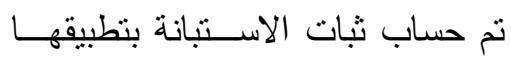

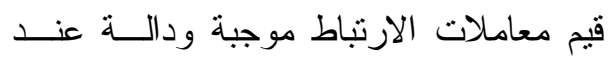

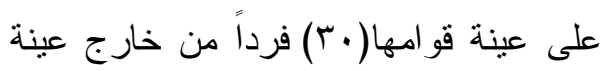

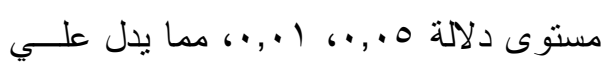
البحث، ونت حساب ثبات الاستبانة باســتخدام (ألفا كرونباخ)، وذلك باستخدام برنامج الرزم

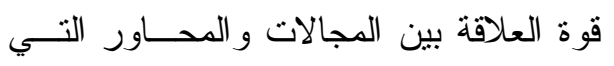

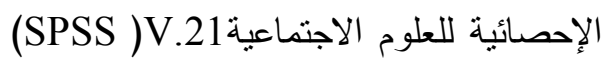

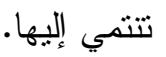
Social Packagefor Statistical

Sciences

جدول ( ) قيم معاملات الثبات "ألفا" لمحاور و الاستبانة ككل

\begin{tabular}{|c|c|c|c|}
\hline معامل ثبات ألفا & عدد العبار ات & المحاور & م \\
\hline$\cdot, 9 \cdot r$ & 7 & تخطيط و إدارة الموارد البشرية & 1 \\
\hline$\cdot, \wedge \circ \varepsilon$ & 7 & خصائص الكادر الوظيفى & $r$ \\
\hline$\cdot, 9 r$ & $\Lambda$ & التوظيف و الاختيار & $r$ \\
\hline$\cdot, \wedge 91$ & 0 & الأنشطة التعريفية للموظفين & $\varepsilon$ \\
\hline$\cdot, 9.0$ & 0 & التطوير الوظيفى & 0 \\
\hline$\cdot, 9 \pi$ & $\mathrm{V}$ & تخطبط الأداء وتقويمه & 7 \\
\hline$\cdot, 91 \wedge$ & 0 & الترقيات و الحو افـــــز الأخرى & $\mathrm{V}$ \\
\hline$\cdot, \wedge \vee$ & 0 & إنهاء الخدمة & $\Lambda$ \\
\hline$\cdot, 9 T Y$ & $\mathrm{~V}$ & المناخ المؤسسى و استبقاء الموظفين & 9 \\
\hline$\cdot, \wedge \wedge 9$ & $\varepsilon$ & التعيي. & 1. \\
\hline$\cdot, 97$ & 01 & الاستبانة ككل & \\
\hline
\end{tabular}




$$
\begin{aligned}
& \text { ونم حساب الوزن النسبي، أب درجة } \\
& \text { المو افقة على كل عبارة من المعادلة التالية: }
\end{aligned}
$$

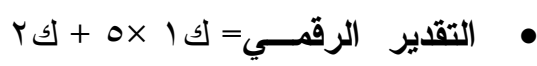

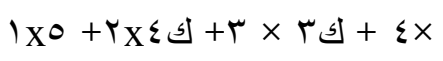

$$
\begin{aligned}
& \text { • حساب الوزن النسبي= }
\end{aligned}
$$

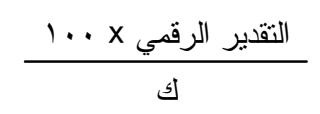

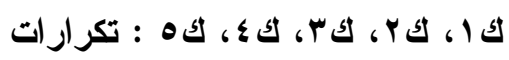

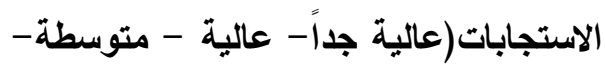

منخفضة - منخفضة جداً)،على الترتيب.

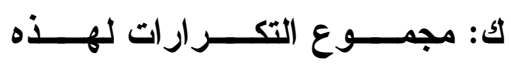

$$
\text { الاستجابات (حجم العينة). }
$$

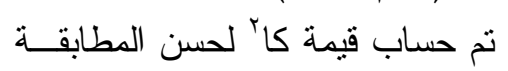

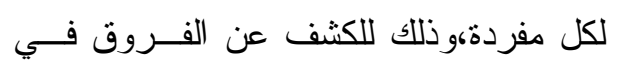

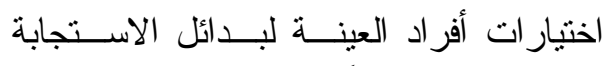

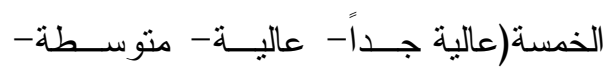
منخفضة - منخفضة جداً)،

تحليل التباين أحادي الاتجاه لتحديــد

الفروق بين أفر اد العينة حسب متغير الوظيفة وسنو ات الخبرة علي محاور الاستبانة. • اختبار"ت"لتحديد الفروق بين أفر اد العينة التهاته حسب متغير النوع علي محاور الاستبانة. نتائج الارسة الميدانية:

سيتم في البداية عرض نتائج اختبــار

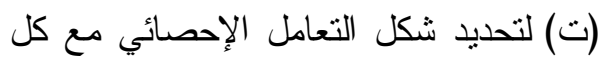
محور، هل سيكون في ضو ء العينة الكلية أم

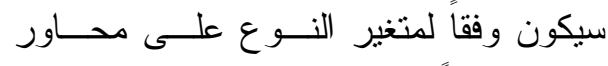

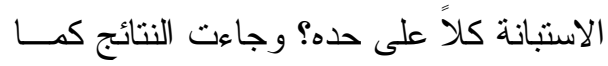
هي موضحة بالجدول الآتي:

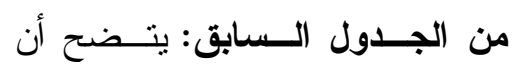

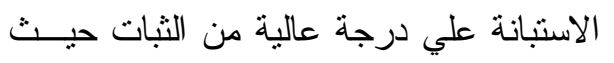

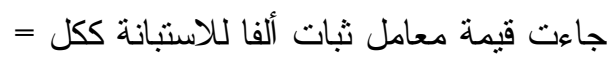

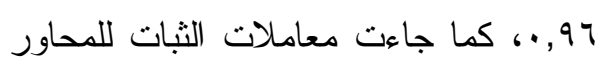

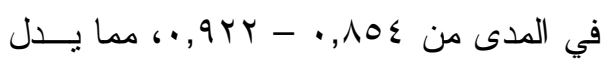
علي ثنات الاستبانة.

وتم حساب معامل الصدق الذاتي للاستبانة

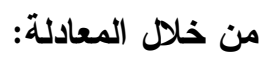

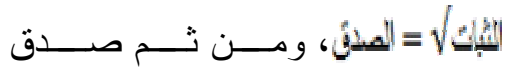

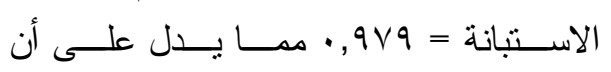

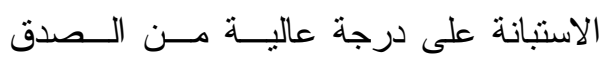
و الثبات.

\section{المعالجة الإحصائية:}

تمت المعالجة الإحصائية باســتخدام برنامج الرزم الإحصائية للعلوم الاجتماعيــة الإسـة Statistical Package for (SPSS)v.21 Social Sciences

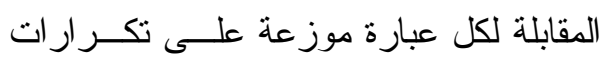
الاستجابات (عالية جداً- عالية - متوسطة-

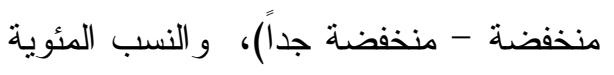

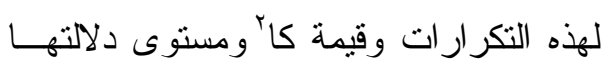
و الأوزان النسبية و الترنيب. حساب الوزن النسبي لعبار ات الاستبانة:

\begin{tabular}{|c|c|c|c|c|}
\hline منذاً & منذفضة & متوسطة & عالية & جالَّ \\
\hline 1 & r & $r$ & $\varepsilon$ & 0 \\
\hline
\end{tabular}

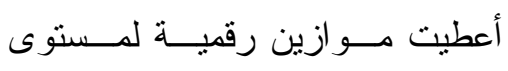
الاستجابة كما يلي : 
جدول (•) قيمة "ت" للفرق بين متوسطي استجابات عينة الدراسة حسب متغير

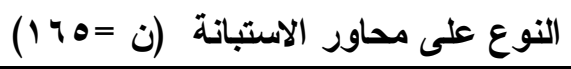

\begin{tabular}{|c|c|c|c|c|c|c|c|}
\hline مستوي الالاية & الدرجية & "تيمة & الالمعيار اف & المتوسط & العدد العد & النوع الن & المحاور \\
\hline \multirow{2}{*}{ غير دالة } & \multirow{2}{*}{ אדו } & \multirow{2}{*}{$\cdot, 7 \cdot 1$} & $0, \vee \wedge$. & $1 \varepsilon, \wedge V$ & 90 & ل فكر & \multirow{2}{*}{ تخطيط و إدارة المو ارد } \\
\hline & & & $\varepsilon, 9 \vee 0$ & 1ะ, & $\mathrm{V}$. & أنثي & \\
\hline \multirow{2}{*}{ غير دالة } & \multirow{2}{*}{ 17 - } & \multirow{2}{*}{$\cdot, Y q \vee$} & $7,1 \cdot V$ & $1 V, \wedge 0$ & 90 & ذكر & \multirow{2}{*}{ خصائص الكادر } \\
\hline & & & $0, \wedge \vee Y$ & IV,OV & $\mathrm{ve}$ & أنثى & \\
\hline \multirow{2}{*}{ غير دالة } & \multirow{2}{*}{ r } & \multirow{2}{*}{$\cdot, 109$} & 1,109 & rT,00 & 90 & ذكر & \multirow{2}{*}{ التوظيف و الاختيار } \\
\hline & & & $\Lambda, 1$ \% & Tr,T & $\mathrm{V}$. & أنثي & \\
\hline \multirow{2}{*}{ غير دالة } & \multirow{2}{*}{ rד } & \multirow{2}{*}{$\cdot, 0.1$} & $0, Y 97$ & $|\varepsilon, \wedge|$ & 90 & ذكر & \multirow{2}{*}{ اللشطة التعريفية } \\
\hline & & & $0,1 K r$ & $10, r T$ & $V$. & أنثي & \\
\hline \multirow{2}{*}{ غبر دالة } & \multirow{2}{*}{ r } & \multirow{2}{*}{$\cdot, 1 \leq 1$} & $0,1 Y$. & $1 \leq, \wedge r$ & 90 & ل & \multirow{2}{*}{ التطوير الوظيفي } \\
\hline & & & $0, Y V_{1}$ & $1 \leqslant, V$. & $\mathrm{V}$. & أنثى & \\
\hline \multirow{2}{*}{ غير دالة } & \multirow{2}{*}{ 17 - - } & \multirow{2}{*}{$\cdot, 19$} & $V, \cdot v \cdot$ & $r \cdot, 1 \leq$ & 90 & ذكر & \multirow{2}{*}{ تخطيط الأداء وتقويمه } \\
\hline & & & $7, \leqslant \leq 0$ & $r \cdot, r \leq$ & $\mathrm{V}$. & أنثي & \\
\hline \multirow{2}{*}{ غير دالة } & \multirow{2}{*}{ (17 - (19 } & \multirow{2}{*}{$\cdot, Y \backslash \leq$} & $0, Y \cdot 1$ & $1 \varepsilon, r Y$ & 90 & ذكر & \multirow{2}{*}{ الترقيات الُْ الحو افــــز } \\
\hline & & & $0, \ldots 7$ & $1 \varepsilon, 0 r$ & $\mathrm{~V}$. & أنثي & \\
\hline \multirow{2}{*}{ غير دالة } & \multirow{2}{*}{ (7T } & \multirow{2}{*}{ •, OY7 } & $\varepsilon, 991$ & $1 \leq, 0 Y$ & 90 & ذ ل & \multirow{2}{*}{ إنهاء الخدمة } \\
\hline & & & $\varepsilon, 9 \vee$. & $1 \leqslant, 94$ & $\mathrm{~V}$. & أنثي & \\
\hline \multirow{2}{*}{ غير دالة } & \multirow{2}{*}{ (7t } & \multirow{2}{*}{$\cdot, \leqslant Y 0$} & $7,9 \wedge 7$ & $r \cdot r V$ & 90 & ذكر & المناخ المؤسسي \\
\hline & & & $7, \vee 0 \leq$ & $r \cdot, \Lambda r$ & $v$. & أنثى & و استبقاء الموظفين \\
\hline غن (دالة & سד & $.7 \mathrm{Y}$ & $\varepsilon, 101$ & $11, \wedge \Lambda$ & 90 & ذكر & \\
\hline & & & $\varepsilon, \Gamma \leq r$ & 11,94 & $V$. & أنثى & \\
\hline
\end{tabular}

من العرض السابق يتضح أن متغير

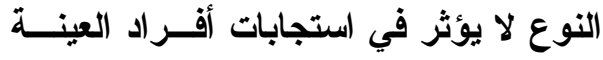
على محاور الاستبانة.

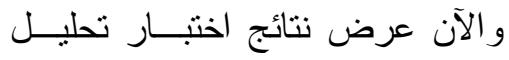

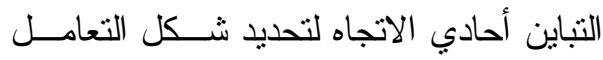

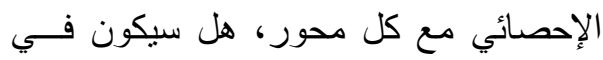

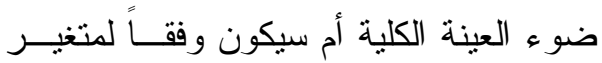

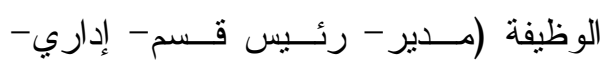

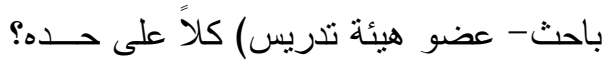

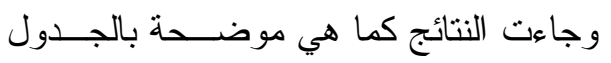
الآتي:
من الجدول السابق يتضح أنسه: لا توجد فــروق ذات دلالـــة إحــصائية بــين متوسطي درجات استجابات عينة الدراســة حسب متغير النوع حول محــاور الاســنبانة

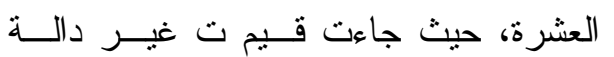

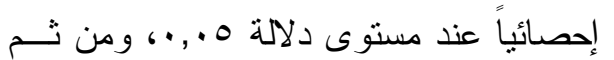

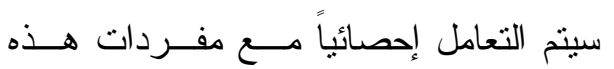
المحاور في ضو ء العينة الكلية. 
جدول (ا) نتائج تحليل التباين أحادي الاتجاه لمعرفة دلالة الفروق بين متوسطات درجات أفراد العينة حسب متغير الوظيفة على محاور الاستبانة

\begin{tabular}{|c|c|c|c|c|c|c|}
\hline مستوي & فَّمة & المتوبعات & الحربية & المزبعات & مصدر التباين & المتغير التابع \\
\hline غير دالة & $\cdot, \vee \vee \varepsilon$ & $\begin{array}{l}r r, \cdot 0 \\
r q, v q \varepsilon\end{array}$ & $\begin{array}{l}\varepsilon \\
17 \\
17 \varepsilon\end{array}$ & $\begin{array}{c}9 r, 199 \\
\sum V 7 V, 11 \\
\sum 109,4.9\end{array}$ & داخلين المجموعات الدجمات & تخطيط و إدارة \\
\hline غير دالة & $\cdot, 9 \cdot 9$ & $\begin{array}{l}r r, V \cdot 1 \\
r 0, q \wedge \varepsilon\end{array}$ & $\begin{array}{l}17 \\
175\end{array}$ & $\begin{array}{l}\text { Ir.,N.O } \\
\text { OVOV, ETY } \\
\text { ONAN,YTV }\end{array}$ & دأخل المجموعوعات المبلة & خصائص الوظيفي \\
\hline غير دالة & $\cdot, \wedge \circ \mathrm{V}$ & $\begin{array}{l}07, V \leqslant 9 \\
77, Y \Psi V\end{array}$ & $\begin{array}{l}17 \\
17 \varepsilon\end{array}$ & $\begin{array}{l}r r 7,99 V \\
1.09 V, 99 V \\
1.0 r \varepsilon, 99 \varepsilon\end{array}$ & داخل المجموعوعات الدات & والتوظيف \\
\hline غير دالة & $1, \cdot \leqslant \Lambda$ & $\begin{array}{l}r \Lambda, \Sigma) V \\
r V, I T V\end{array}$ & $\begin{array}{l}17 \\
175\end{array}$ & $\begin{array}{l}11 r, 77 q \\
\varepsilon r \leqslant \cdot, r \cdot v \\
\varepsilon \leqslant 0 r, q \vee 7\end{array}$ & داخل المجموعات الدربة المبلة & للموظفينية الأنشية \\
\hline غير دالة & $\cdot, \vee 0 \leq$ & $\begin{array}{l}r \cdot, Y \backslash \varepsilon \\
r Y, \wedge \vee Y\end{array}$ & $\begin{array}{l}17 \\
178\end{array}$ & $\begin{array}{c}11, .07 \\
\leqslant \mu, 19 r \\
\leqslant r \wedge, r \leqslant \Lambda\end{array}$ & 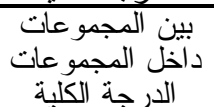 & الوظيفي \\
\hline غير دالة & 1,010 & $\begin{array}{l}71,994 \\
\leqslant 0,049\end{array}$ & $\begin{array}{l}17 \\
178\end{array}$ & $\begin{array}{l}r V 0,97 V \\
V Y \leq \cdot, 710 \\
V 017,70 Y\end{array}$ & دآخل المجموعات الدات & تخطيط الأداء \\
\hline غير دالة & 1, & $\begin{array}{l}r \cdot, 7 q \\
r 0, q \leq \varepsilon\end{array}$ & $\begin{array}{l}17 \\
17 \varepsilon \\
17 \varepsilon\end{array}$ & $\begin{array}{l}\text { IrY,VTI } \\
\leq 101, \cdot r Y \\
\varepsilon r V T, V 9 \varepsilon\end{array}$ & داخل المجموعات الدات & 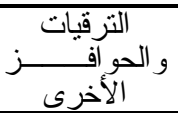 \\
\hline غير دالة & 1,110 & $\begin{array}{l}\varepsilon \varepsilon, .0 Y \\
r \varepsilon, r>9\end{array}$ & $\begin{array}{l}5 \\
17 . \\
175\end{array}$ & $\begin{array}{l}V T, Y \mid r \\
r \wedge \wedge r, r Y \\
\varepsilon .09, Y r 4\end{array}$ & داخل المجميوعات الدات & إنهاء الخدمة \\
\hline غير دالة & $1, \leqslant 0 \wedge$ & $\begin{array}{l}71, \cdot 77 \\
\Sigma 7,7 V\end{array}$ & $\begin{array}{l}17 \\
175\end{array}$ & 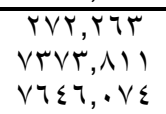 & داخل المجموعات الدات & 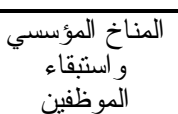 \\
\hline غير دالة & 1,079 & $\begin{array}{l}\text { TV,007 } \\
1 V, 07 \varepsilon\end{array}$ & $\begin{array}{l}5 \\
17 . \\
17 \varepsilon\end{array}$ & $\begin{array}{l}11 \cdot, r r \leq \\
r \wedge) \cdot, r r \leq \\
r 9 r \cdot, \leq \leq \Lambda\end{array}$ & داخل المجموعات المجات & التعييــــــــن \\
\hline
\end{tabular}

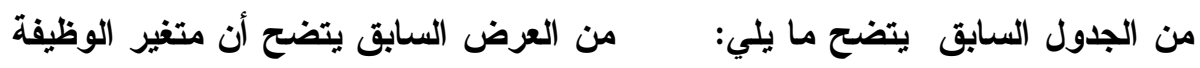

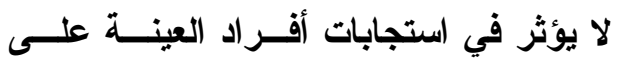
عدم وجود فروق ذات دلالة إحصائية بـين

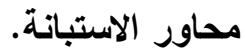
متوسطات درجات استجابات عينة الدراسة و الآن عرض نتــائج اختبــار تحليـلــل

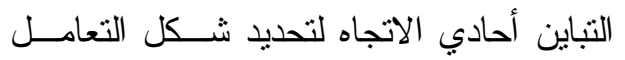
وفقاً للوظيفة على محاور الاستبانة الخمسة، درجات

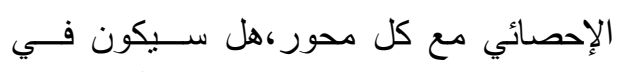

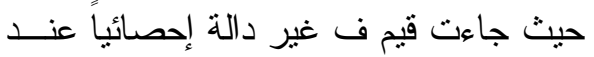
مستوى دلالة ه.,.•، ومن ثم سيتم التعامل

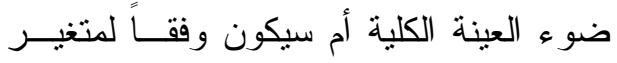

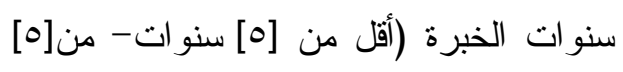

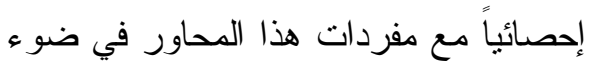

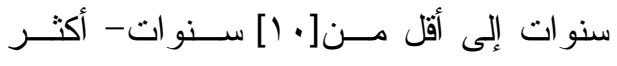
العينة الكلية للار اسة. 
من [ [ [] سنوات)كلاً على حـده؟ وجــاءت النتائج كما هي موضحة بالجدول الآتي: جدول)

نتائج تحليل التباين أحادي الاتجاه لمعرفة دلاكة الفروق بين متوسطات درجات أفر اد العينة حسب

\section{متغير سنوات الخبرة على محاور الاستبانة}

\begin{tabular}{|c|c|c|c|c|c|c|}
\hline مستوى الدلالة & قيمة & متوسط المربعات & درجات & المربعات & مصدر النباين & المتغير التابع \\
\hline غير & $\cdot, \cdot \wedge \varepsilon$ & $\begin{array}{l}\text { r,OrV } \\
\text { r9,970 }\end{array}$ & $\begin{array}{l}r \\
17 r \\
17 \varepsilon\end{array}$ & $\begin{array}{c}0,0 \leq \\
\leqslant 10 \leqslant, Y 00 \\
\leqslant 109, r .9\end{array}$ & بين المجموعات المجموعات & المو ارد البشر وإدارة \\
\hline غير & •, rro & $\begin{array}{l}A, I T r \\
r T, r \leq V\end{array}$ & $\begin{array}{l}r \\
17 r \\
175\end{array}$ & 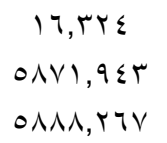 & بين المجموعات المجموعات & خصائص الكادر \\
\hline غير & • , Y TO & $\begin{array}{l}1 \leq, 9 \wedge 7 \\
77,747\end{array}$ & $\begin{array}{l}r \\
17 r \\
175\end{array}$ & $\begin{array}{c}r q, q \vee r \\
1 \cdot V 90, \cdot r 1 \\
1 \cdot 1 r \leq, 99 \varepsilon\end{array}$ & داخل المجموعات المجوعات & التوظيف و الاختيار \\
\hline غير &., 170 & $\begin{array}{c}\varepsilon, 0 \leqslant \\
r V, \varepsilon r \wedge\end{array}$ & $\begin{array}{l}r \\
17 r \\
175\end{array}$ & $\begin{array}{c}9, \cdot \wedge \\
\leq \leq \leq \varepsilon, \wedge 97 \\
\leq \leqslant 0 \%, 9 \vee 7\end{array}$ & داخل المجموعات المجموعات & اللأنشطة التعريفية \\
\hline غير & V & $\begin{array}{l}9, \text { • Aт } \\
\text { rq,9rr }\end{array}$ & $\begin{array}{l}r \\
17 r \\
17 \varepsilon\end{array}$ & $\begin{array}{l}I \Lambda, I V Y \\
\leq r T r, \cdot V T \\
\leq r \wedge \mid, r \leq \Lambda\end{array}$ & بين المجموعات المجموعات & التطوير الوظيفي \\
\hline غير & $\cdot r \leq 7$ & $\begin{array}{l}17, \cdot \wedge r \\
\Sigma \neg, \Sigma \wedge \wedge\end{array}$ & $\begin{array}{l}r \\
17 r \\
17 \varepsilon\end{array}$ & $\begin{array}{l}r r, 17 r \\
V \leq \Lambda \leq, \leq \wedge 9 \\
V 017,70 r\end{array}$ & داخل المجموعات المجموعات & تخطيط الأداء \\
\hline غير & • r. & $\begin{array}{l}9, r 10 \\
r y, r y 7\end{array}$ & $\begin{array}{l}r \\
17 r \\
17 \varepsilon\end{array}$ & $\begin{array}{c}11,7 r \\
\varepsilon Y 00,17 \varepsilon \\
\varepsilon r V r, \vee 9 \varepsilon\end{array}$ & داخل المجموعات المجموعات & و الحو افرقيات الأخرى \\
\hline غير & •, YYT & $\begin{array}{l}0,7 r 0 \\
r \varepsilon, 9 \wedge V\end{array}$ & $\begin{array}{c}r \\
17 r \\
17 \varepsilon\end{array}$ & $\begin{array}{c}11, Y V \\
\Sigma \cdot \Sigma V, 977 \\
\Sigma .09, Y r 4\end{array}$ & بين المجموعات المجموعات & إنهاء الخدمة \\
\hline غير & $\cdot .019$ & $\begin{array}{l}r \leq, T \leq T \\
\leq V, \leq \wedge\end{array}$ & $\begin{array}{l}r \\
17 r \\
17 \varepsilon\end{array}$ & $\begin{array}{c}\leq q, Y q r \\
V \circ 97, V \wedge 1 \\
V \neg \leq 7, \cdot V \leq\end{array}$ & داخل المجموعات الدموعات & و اسنبقاء الموظفيني \\
\hline غير & $\cdot, 19$ & $\begin{array}{l}r, \varepsilon \mid \varepsilon \\
\mid \vee, q \wedge 0\end{array}$ & $\begin{array}{l}r \\
17 r \\
178\end{array}$ & $\begin{array}{c}T, \wedge r v \\
r q|r, T r| \\
r q r \cdot, \varepsilon \leq \wedge\end{array}$ & بين المجموعات المجموعات & التعييــــــــن \\
\hline
\end{tabular}


سيتم التعامل إحصائياً مـــع مفــردات هـــذا المحاور في ضوء العينة الكلية للار اسة.

من العرض السابق يتضح أن متغير سنوات الخبرة لا يؤثز في استجابات أفـــر اد العينة على محاور الاستبانة.
من الجدول السابق يتـــ عـدم

وجود فـروق ذات دلالـــة إحــصائية بـين

متوسطات درجات استجابات عينة الدراســة وفقاً لسنوات الخبرة على محاور الاســتبانة الخمسة، حيث جاءت قـــم ف غيــر دالـــة إحصائياً عند مستوى دلالة ه., •، ، ومن ثـم

جدول (^)

المتوسطات والاتحر افات المعيارية لمحاور الاستبانة، ونسبة توافرها بجامعة صحار وفقاً لاستجابات عينة الدر اسة

\begin{tabular}{|c|c|c|c|c|c|}
\hline الترتيب & درجة التوافر & نسبة التو افر & الالحمراف & المتوسط & المحاور \\
\hline 0 & متوسطة & $\% \circ \wedge, 7$ & ד, & r,q & تخطيط و إدارة المو ارد البشرية \\
\hline r & متوسطة & $\% \circ 9,1$ & $7, \cdot 1 \mathrm{r}$ & $Y, 97$ & خصائص الكادر الوظيفي \\
\hline$\varepsilon$ & متوسطة & \%०ᄉ, т & $\wedge, 1 \leq \varepsilon$ & r,qr & التوظيف و الاختيار \\
\hline$\checkmark$ & متوسطة & $\% 0 \cdot, 1$ & $0, Y 17$ & r & الأنشطة التعريفية للموظفين \\
\hline$\wedge$ & متوسطة & $\% \leq 9,1 \pi$ & $0, r \cdot \Lambda$ & $r, 90$ & التطوير الوظيفي \\
\hline 1 & متوسطة & $\% \circ \vee, \wedge$ & $\neg, \vee \wedge 1$ & $r, \wedge 9$ & تخطيط الأداء وتقويمه \\
\hline 1. & متوسطة & $\% \varepsilon \wedge, \cdot r$ & $0,1 \cdot 0$ & $r, \wedge \wedge$ & التزرقيات و الحو افــــــز الأخرى \\
\hline 9 & متوسطة & $\% \leq \wedge, 9 \vee$ & $\varepsilon, 9 \vee 0$ & $r, q \leq$ & إنهاء الخدمة \\
\hline r & متوسطة & $\% \circ \wedge, \vee \leq$ & $\top, \wedge \vee$ & $r, q \leq$ & المناخ المؤسسي و استبقاء الموظفين \\
\hline 1 & متوسطة & $\% \circ 9,0$ & $\varepsilon, r r$ & $r, q \wedge$ & التعييـــــــن \\
\hline
\end{tabular}

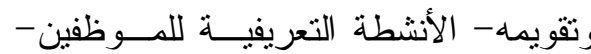
التطوير الوظيفي- إنهاء الخدمة - الترقيات من الجدول الـسابق: يتـضح أن

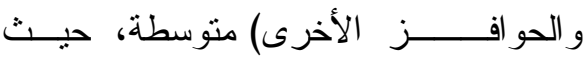
درجة نو افر محاور الاستبانة جاءت علـى

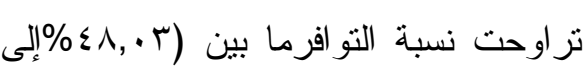

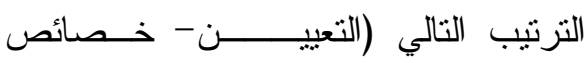
الكادر الوظيفي- المناخ المؤسسي و اســتبقاء

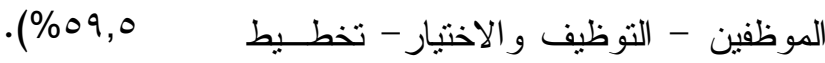
و إدارة الموارد البــشرية- تخطــيط الأداء 
أنشارت إلى أن هنالك وعياً عالياً ووضـــوحاً

لمفهوم التخطيط الاستر اتيجي لإدارة الموارد البشرية ، و ارتفاعا في الممارسات الفعليــة للتخطيط بين دوائر نتمية الموارد البـشرية ولثية

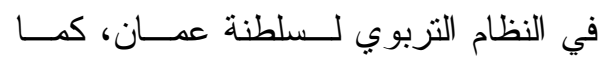
توصلت إلى وجود مجموعة مــن العو ائــق التي تحد فاعلية تخطيط المـــوارد البـشرية جاء في مقدمنها ضعف مستوى المـشـاركة

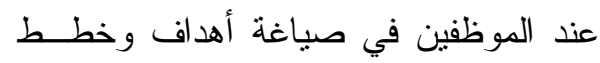
الموارد البشرية. وجاء في المرتبة الأخيرة

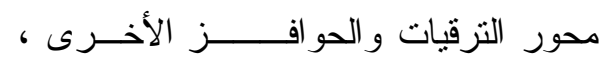
ويعزو الباحث ذلك إلى عدم رضى العاملين

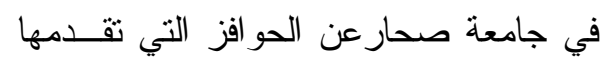
الجامعة لهم ، حيث لا يوجد نظــام فعـال

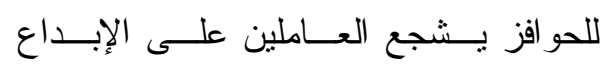

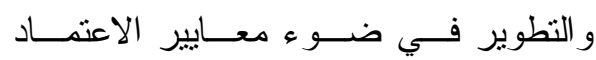

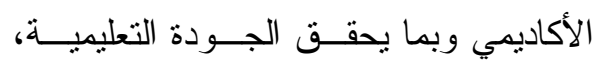
ويتفق ذلك مع در اسة(مقابلة، • 1 ب) و التي

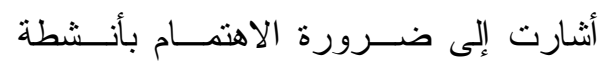
المو ارد البشرية وضع الحو افز و المكافــآت الفي

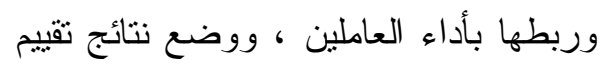

الأداء منطلقا رئيسيا في عمليات النزقية . وتوصلت الدراسة الى مجموعة من النتـائج أهمها : وتوص:

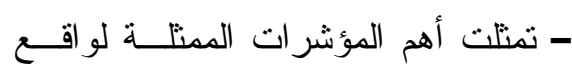

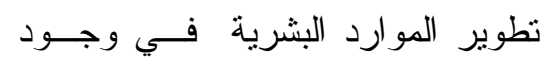
أهداف و اضحة ومحددة ؛ولكن التطبيق
ويعزو الباحث هذه النتيجة إلـى أن

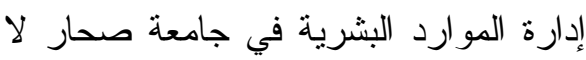

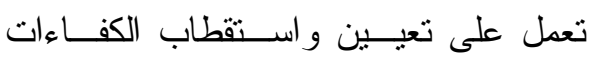
البشرية كهدف و إنما تستقبل الأوامــر مــن فئن عمداء الكليات بحيث بطلب منها الاعــلان عن وجود وظائف في حال كانت الجامعــة

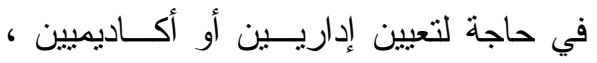
وبذلك يكون دور ها فـي اســتقبال طلبــات

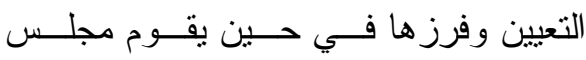
الجامعة بعملية التعيين. كما يعزو الباحث ذلــــ إلـى عــدم رضاء أفر اد العينة من العاملين في جامعــة إحسة

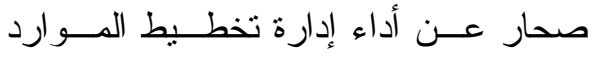
البشرية في جامعة صحار ، فهي تقوم بدور روتيني وتقليدي ، ومن ثم لا تقوم بــدور ها

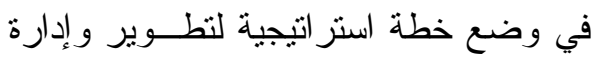

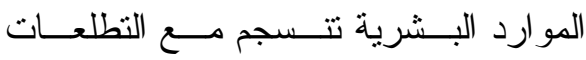
العالمية ونو اكب المستجدات و التغيرات التي تطر أ على عــالم الإدارة لتحقيــق الجــودة

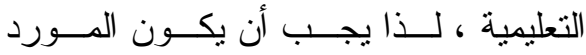
البشري في جامعة صحار أكثر فاعلية مــن خلال الاهنمام بعمليات تـدريب الكــوادر البشرية، علاوة علــى تخطــيط المــوارد

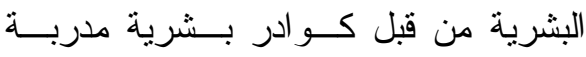

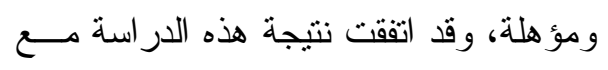

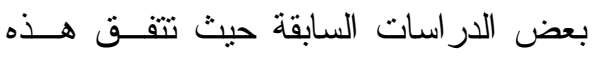

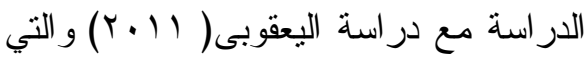


البشرية ، سيادة الطابع النظري علـى

$$
\text { بر امج التطوير }
$$

- من أهم المقترحات اللازمـــة لتطـــوير

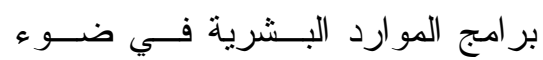

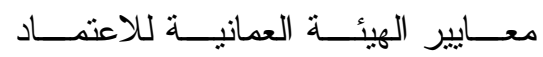
الأكاديمي تقديم البر امج التدريبية الفعالة

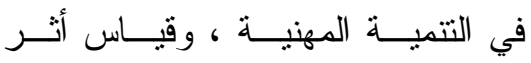

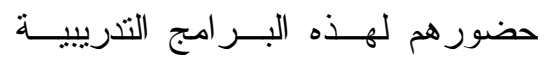
ومتــابعتهم علـــى أرض الو اقـــع فــي

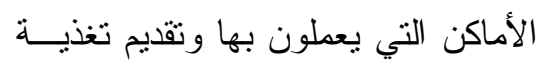

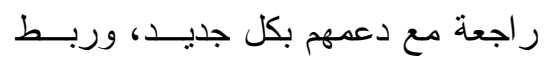

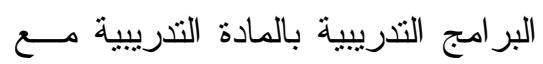

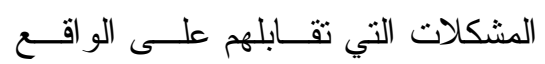
و السلبيات الموجودة ، و التزكيـز فــي البرامج التذريبية على الجانب العملـي ولي ولئي

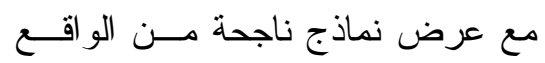
الفعلي لتكون مثالا يحتذى به. - لا توجد فروق ذات دلالة إحصائية بين متوسطات درجات اســتجابات عينــة الدر اسة وفقاً للوظيفة في إدر الى عينـــة

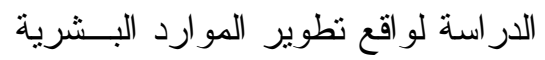
في جامعة صحار في ضـــوء معسايير

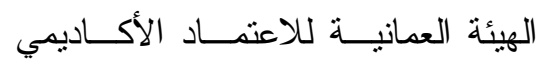
ومدى إدر اكهم لمعايير جودة الاعتماد - لا توجد فروق ذات دلالة إحصائية بين متوسطات درجات اســتجابات عينــة الدراسة وفقاً لمتغير الخبرة إدرات الك عينة
في التطـــوير يحتــاج لاســتراتيجيات إبداعية بعيدة النمطية. - ضرورة العمل على إيجاد نقافة تتظيمية

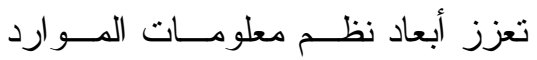
البشرية في البيئة التظظيمية، و الارتقـــاء

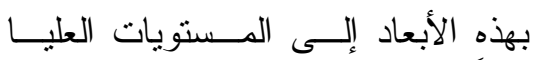

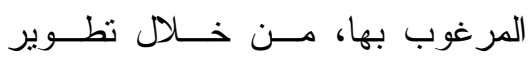

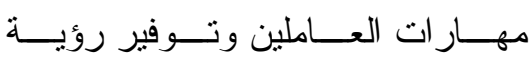

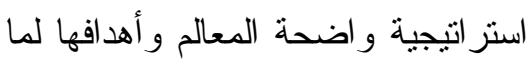

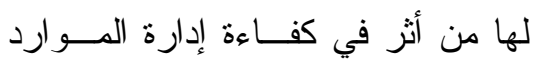
البشرية - وجود قصور في بعـض المؤشــرات

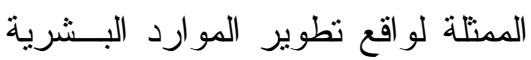

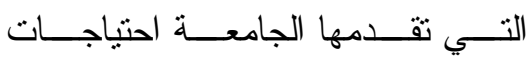
الموظفين المهنية و التدريبية ، و مو اكبة المحتوى للمستجدات العالمية. - من أهم معايير جودة نطوير المــوارد

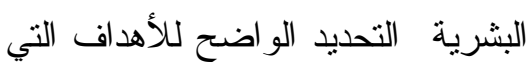
تبنى الخطط على أساســـها ،الــشمول

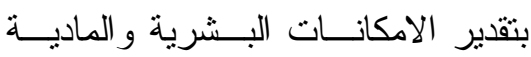
،المتابعة و التقويم من خلال ملاحظــــة الخطط أثناء تطبيقها و التغلب على مــــا قد يو اجهها من مشكلات و الافادة مسن الخبرات الماضية للتطوير المستقبلي مئن - من أهم المشكلات و المعوقـات التــي تو اجه تتفيذ بــر امج تطـــوير المــوارد 
إن هذا التصور لا ينطلق من هدف

تطوير أساليب الموارد البشرية أو بــر امج

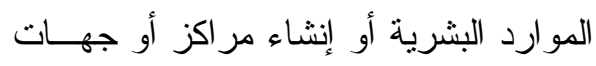

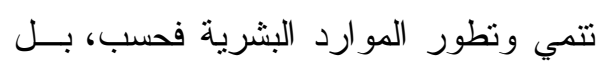
يسهم في تظوير منظومة الموارد البـشرية في جامعة صحار بشكلٍ منكامل ويتــن ضن هذا التصور (أهـــداف التــصور المقتــرح،

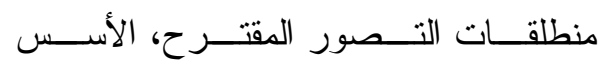
و المبادئ التي يُينْى عليها التصور المقترح، ومكونات التصور المقترح، و العقبات التـي تو اجه تتفيذ التصور المقتـرح، ثــم ســبل التغلب عليها). أولاًِ- أهداف التصور المقترح: يهدف التصور المقتر ح إلى: - الاستفادة من التقدم المعرفي و التطـــور التقني في تجديد الإطار الفكري لمعايير الهيئة العامة للاعتماد الأكاديمي. - استخدام الأسـاليب و الوســائل الحديثــة لتطوير الموارد البشرية بجامعة صحار في ضوء معايير الهيئة العامة العمانيــة للاعتماد الأكاديمي.

- تعديل الهيكل التظظيمي الحالي لجامعــة صحار لبساهم بدور كبير فــي تطــوير الموارد البشرية ويخدم جميع العـاملين

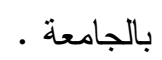

الدر اسة لو اقع تطوير الموارد البــثرية في جامعة صحار في ضـــوء معــايير

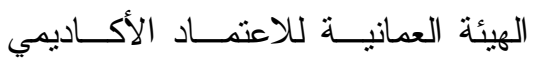
ومدى إدر اكهم لمعايير جودة الاعتمـــاد و المشكلات التي تواجه تتفيــذ معــايير - الاعتماد - تباين استجابات عينــة الدر اســـة وفقـاً للوظيفة(مدير - رئيس قسم - عضو هيئة تذريس باحــث - إداري ) فـي إدرالك عينة الدر اسة لمعايير تطوير المــوارد البشرية في جامعة صحار في ضــو

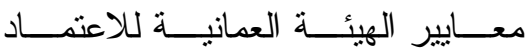
الأكاديمي. - تباين استجابات عينـــة الدر اســـة وفقــاً للوظيفة فـي إدرالك عينــة الدراســـة

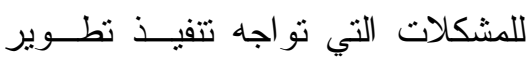
الموارد البشرية في جامعــة صــــار ومحدودية الطابع التطبيقي في معـايير الميئة العمانية للاعتماد الأكاديمي ولهي لهمية توصيات الدراسة :

توصي الدراسة بوضع تصور مقترح لتطوير الموارد البشرية في جامعة صــحار في ضوء معايير الهيئة العمانية للاعتمــاد : الأكاديمي في ضوء التصور المقترح لمنظومة تخدم الموارد البشرية وذلك للإجابــة عـن السؤ ال الأخير من أسئلة الدر اسة. 


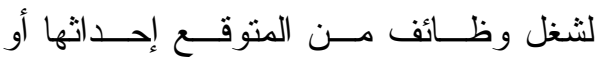
ثانيا- مكونات التصور المقترح:

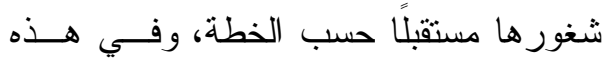

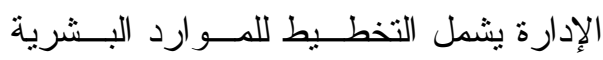
نوعين من التخطيط، و هما: التخطيط لتوفير احتياجات الموارد البشرية و التخطبط للمسار الوظيفي.

ج- إدارة التوظيف في ضوء معايير الهيئة العمانية للاعتماد الاكاديمي:

يقع على عاتق هذه الإدارة مسؤولية مهمات استقطاب واختيار وتعيين العـاملين في الجامعة، وهذا لا يعني أن هذا القسم هو ونئن الذي يتخذ قرار التوظيف و إنما مهمته عبارة عن إيضاح كل الكفايات اللازمـــة و المهــام

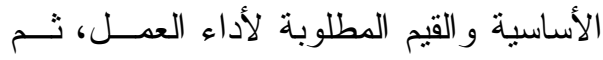
إجر اء عملية تتسيق الجهود مع الإدارة العليا

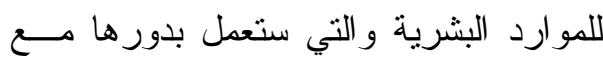
الإدارة العليا للجامعة لاتخاذ القرار المناسب

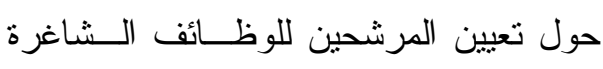

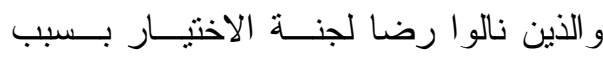
مؤ هلاتهم وتخصصاتهم وخبرتهم المناسبة.

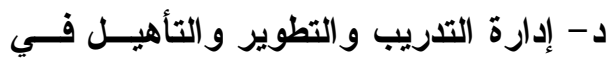
ضوء معايير الهيئة العمانية للاعتمــاد ولئي الاكاديمي:

يهنم هذا القسم بعملية تطوير ونتميــة

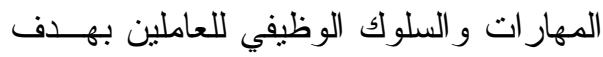

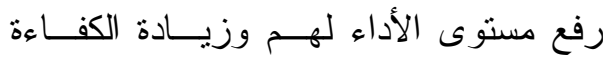
الإنتاجية لتحقيق أهداف الجامعة، وتـستخدم

تعمل الدر اسة على وضــع تــصور

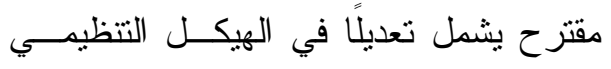
الحالي للجامعة لتنمية الموارد البشرية فـي لني

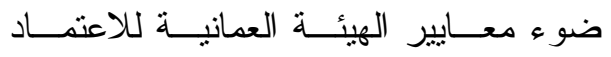

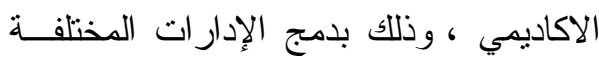
الموزعة في مو اقع مختلفة من الهيكـلـل فـي الإدي

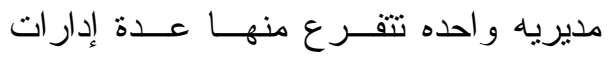
: متخصصد على النحو الثالي :

أ - تصميم إدارة الموارد البشرية في ضوء

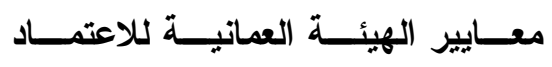
الاكاديمي: وتتمل أربعة أقسام،هــي: تـصميم

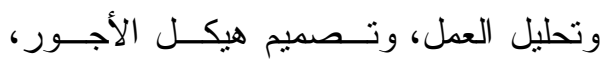

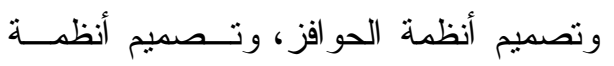
مز ايا وخدمات العاملين. ب- إدارة التخطيط للموارد البـشرية فـــي ضوء معايير الهيئة العمانية للاعتمــاد

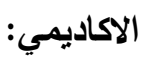

برتبط التخطـــيط للـــــوارد البـشرية

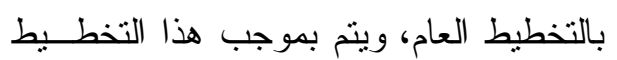

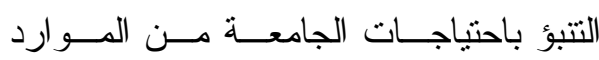
البشرية لفترة معينة في المستقبل، كما يسعى بله

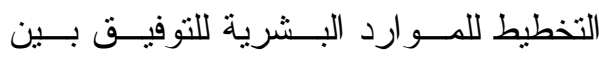
العرض من الأفر اد على رأس العمل وبــين

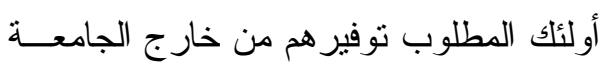




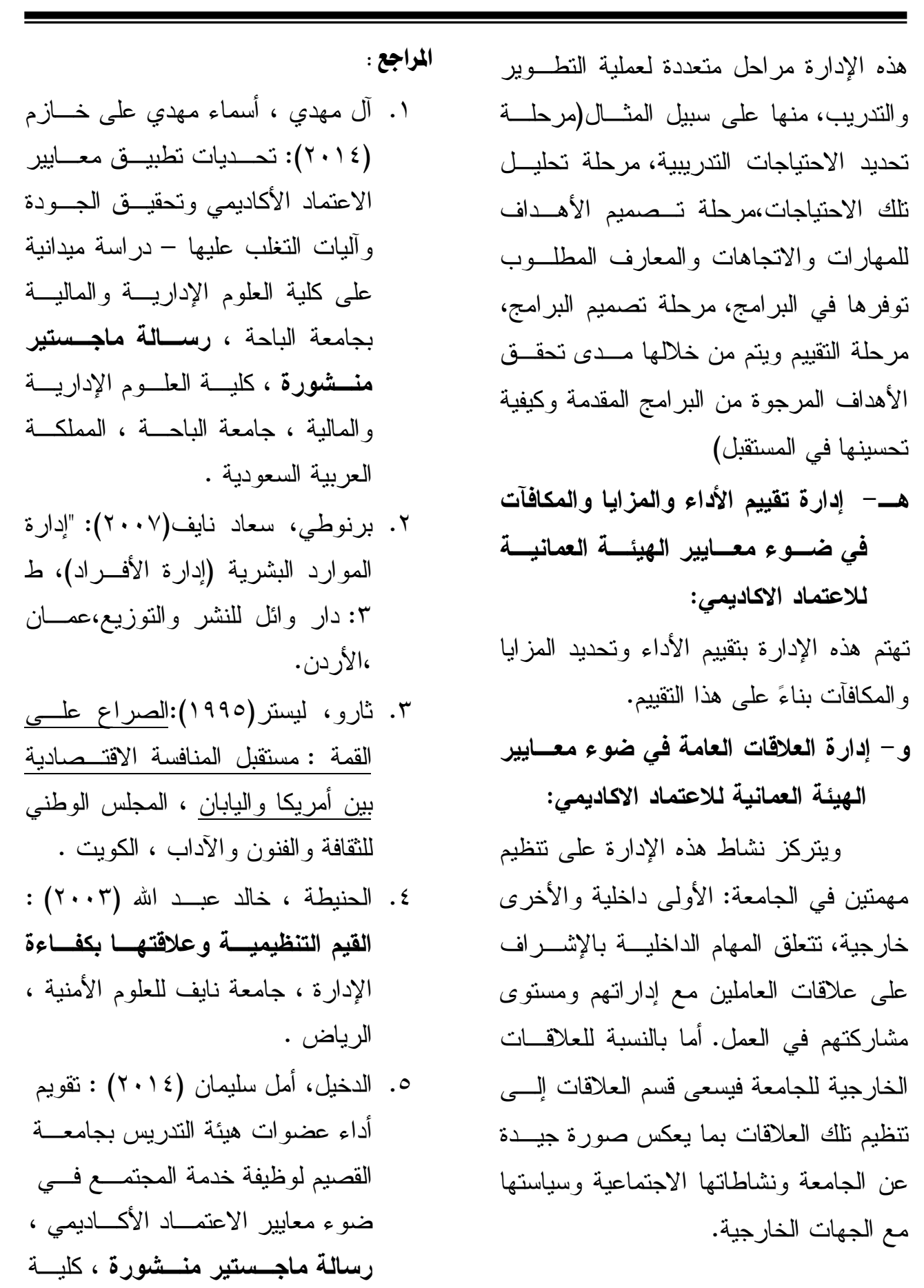




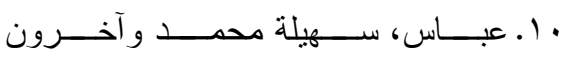

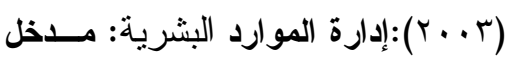

استراتيجي، دار و ائل للطباعة و النـشر ، النش

$$
\text { عمان، الأردن. - مان. }
$$

1 ا. العريمي ، حليس بن محمد بـن حلـيس

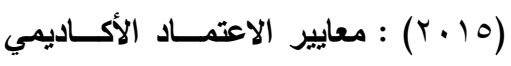

لكليات التربية في سلطنة عمان ، كليــة

التربية ، جامعة صور ، سلطنة عمان.

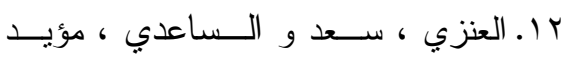

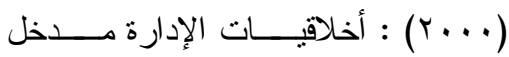

التكوين في منشآت الأعهــال ، المجلـــة الإدة

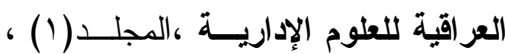

$$
\text { العدد (T) ، ص V V-0.0. }
$$

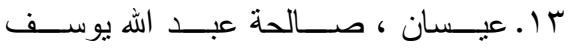

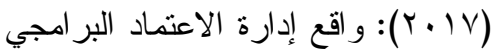

في جامعة السلطان قـابوس ، المــؤتمر

العلمي السنوي الرابع والعشرين : قيادة

التعليم وإدارته في الوطن العربي : الواقع

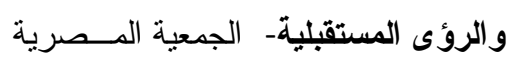

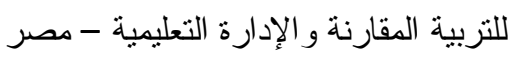

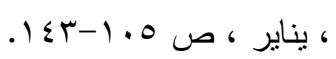

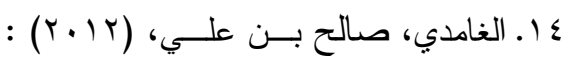

تجربة جامعة الإمام محمد بـن سـعود

الإسلامية في بناء نظام داخلي للجـودة،

منـشـور ات إدارة الجــودة والاعتمــــاد

الأكاديمي بجامعة الإمام محمد بن سعود

الإسلامية. الرياض.
التزبية ، جامعة القـــيم ، المملكــة العربية السعودية

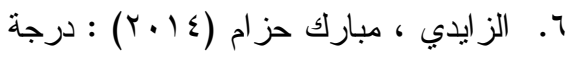

تطبيق معايير الاعتماد فــي الجامعـات

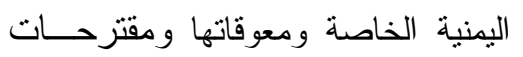

النطوير ، رسالة دكتوراه منشورة ، كلية

التربية ، جامعة اليرموك ، الأردن •

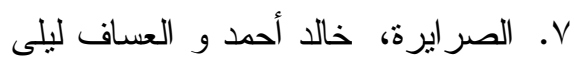

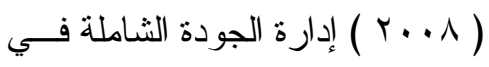

مؤسسات التعليم العالي بين النظريــة

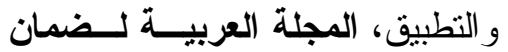
جودة التعليم الجامعي، جامعة العلوم و

التكنولوجيا، صنعاء، اليمن،العدد (1)

A. الطاسان، نجلاء عبدالرحمن (10 ب ب)

: درجة تطبيق معسايير الاعتمــاد و

ضمان الجــودة فــي إدارة شــــؤون

الطالبات و الخدمات الطلابية بجامعــة

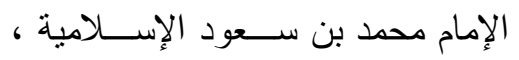

مجلة رابطة التربية الحديثة ، المجلد

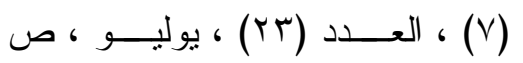
$. T Y V-1 T V$

9. الطهــر اوي ، عبـــــ المــنعم رمــضـان

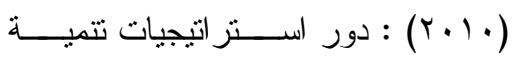

الــــوارد البـشرية فــي تطــــير الأداء

المؤسسي في المنظمات غير الحكوميــة

في غزة ، رسالة ماجستير غير منشورة ، الجامعة الإسلامية ، غزة . 
الأردن تصور مقترح ، رسالة دكتــوراه

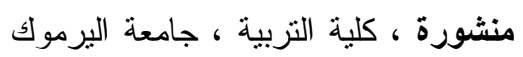

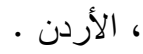

9 1.مقابلة ، ميسون محمود أحمد بردويل

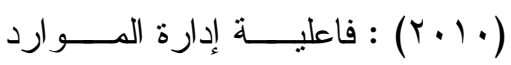
البـشرية فــي الجامعـــات الأردنيــة الحكومية وسبل تطوير هـــا ، رســالة الجئة دكتوراه منشورة ، كليــة التربيــة ، جامعة البرموك ، الأردن .

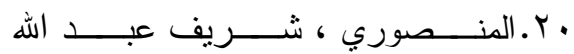

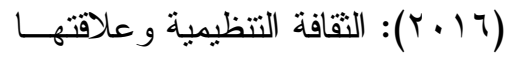

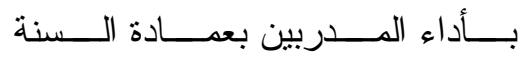
التحضيرية بجامعة الملك سعود، مجلة

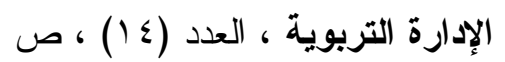
.rNV-rNI

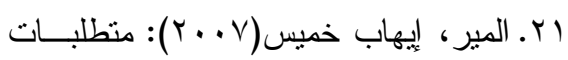
تتمية الموارد البـشرية لنطبيــق الإدارة الإلكترونية، دراسة تطبيقية على العاملين

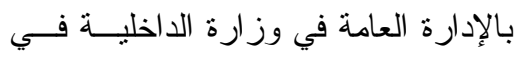
مملكــة البحــرين، رســـالة ماجسـتير

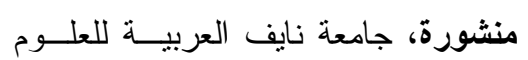

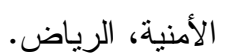

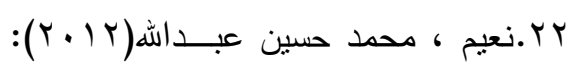

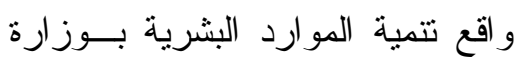

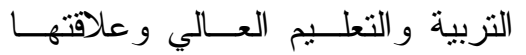

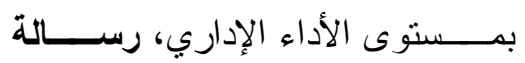
ماجستير غير منشورة، قسم أصـــول
1 ا الفــز ارى، محمـــد بــن أحمـــد بـن

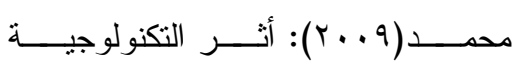

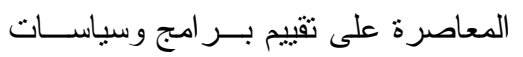

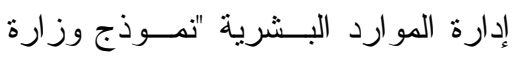
التربية و التعليم بسلطنة عمــان، رســالة دكتور غاه غيـر منـشـورة ، قـسم إدارة الأعمال، كلية الاقتصاد، جامعة تشرين، الجمهورية العربية السورية. 7 ا ـ المجاهد ، إير اهيم محمــــ إســماعيل (Y. IV)

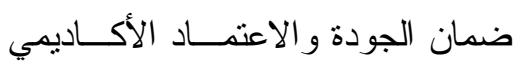
وعلاقته بجودة الخدمة التعليمية فـي لئي جامعة ذمار - در اســـة ميدانيــة لآر اء

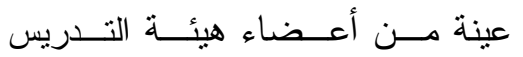

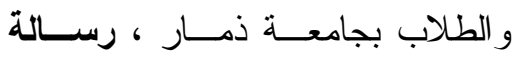

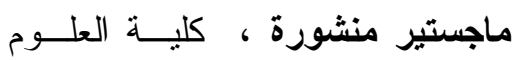

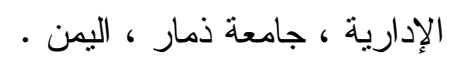
IV ممارسات إدارة المو ارد البشرية فــي تحقيق العدالـــة الاجتماعيــة در اســـة ميدانية من وجهة نظـــر عمــال إدارة

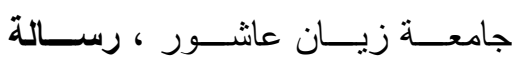

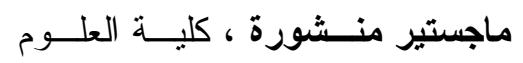

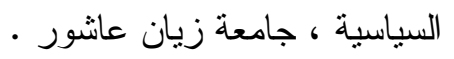

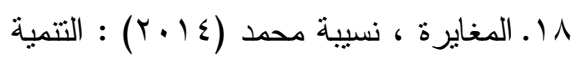

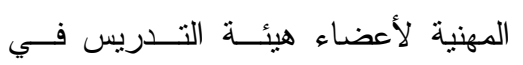

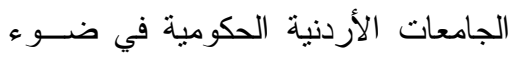

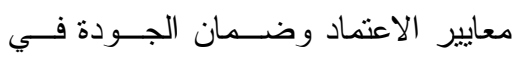


Administrative Leadership to

Advance High - Quality teaching and Learning in Higher Education.

28. David Patton( 2015)

Performance Indicators in Higher

Education,

Northern Ireeland Analysis

2013, Statistics and Research

Branch (Tertiary Education),

Department for Employment and learning.

29. Havvy,M \& novicevic , $\mathrm{m}$ (2003) globe human resource management its role in globel network , Research and practice in human resource management.

30. Kolb,David

A.(2014):

Experiential Learning :

Experience as the Source of Learning and Development $\left(2^{\text {nd }} E d\right) ， 5-6$. By Prentice Hall, Inc .

31. Mc Goldrick \& Stewart , J (1996):The

HRM-HRD nexus, in $\mathrm{J}$.Stewart and $\mathrm{J}$. McGoldrick (rds) :HRD ;

$$
\begin{aligned}
& \text { التزربيـــة، كليــة التربيـــة، الجامعـــة } \\
& \text { الإسلامية، غزة. }
\end{aligned}
$$

r r. النمر ، سعود محمد و خاثقجي ، هانى

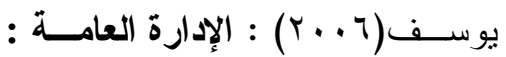

الأسس و الوظائف ، الطبعة السادسة ، مكتبة الثقري ، الرياض •

ـr.الهيئة العمانية للاعتماد الأكسـاديمي

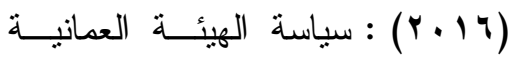

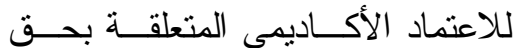

الهيئة في الحصول على المعلومــات

و الوصول للأشخاص في المؤسـسـات

التــي تخــضع لعمليــات المر اجعــة

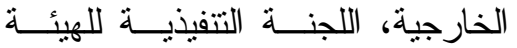

العمانية للاعتماد الأكاديمي. عمان.

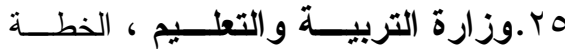

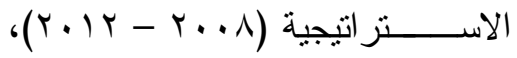

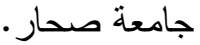

דr.اليعقوبى، علي بن راثد بـن ســالم

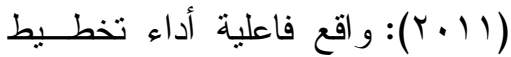

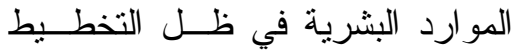

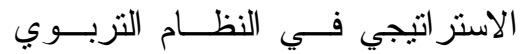

بسلطنة عمان، رسالة ماجستير غيـر

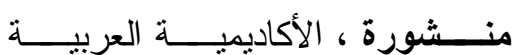

البريطانية للتعليم العالي، الدانمارك.

27. Crowley , Dawn ( 2004) : Reconciling Educational Excellence with Organizational Efficiency : 
33. Soltani. Ebrahim\& Meer, R. ‘ \& Williams Terry, (2009):M.

A Contrast of HRM and TQM Approaches to Performance Management: Some Evidence ‘British Journal of Management ، 16 (3) เpp. $48-59$.
Perspectives Strategies and Practice ,London .

32. Mikol, M, (2007): Quality assurance In Australian Higher Education Acase study of the University of Weslern, Sydney nepean, (on line). www. Oecd.org/ dataoecd. 27-62. 